\title{
Revision of the species of Chaetocnema from Madagascar (Coleoptera: Chrysomelidae: Alticinae)
}

\author{
MAURIZIO BIONDI \\ Dipartimento di Scienze Ambientali, University of L'Aquila, 67010 Coppito (AQ), Italy; e-mail: biondi@univaq.it
}

Key words. Coleoptera, Chrysomelidae, Chaetocnema, Madagascar, taxonomy, biogeography, key

\begin{abstract}
The species of flea beetles of the genus Chaetocnema Stephens, 1831 occurring in Madagascar are revised. Four new species (C. cachani, C. hygrophila, C. malgascia and C. orophila) are described and five species (C. bamakoensis Bechyné C. confinis Crotch, C. fuscipennis Scherer, C. ganganensis Bechyné and C. picipes Stephens) are added to the Madagascar fauna. The following new synonymies are proposed: C. wollastoni Baly, $1877=$ C. fraterna Harold, 1879 syn. nov. $=$ C. monomorpha Bechyné, 1964 syn. nov.; C. pulla Chapuis, $1879=$ C. tantilla Weise, 1910 syn. nov.; C. bilunulata Demaison, $1902=$ C. sylvia Bechyné, 1964 syn. nov.; C. vadoni Bechyné, $1948=$ C. alaotrensis Bechyné, 1964 syn. nov.; C. gregaria Weise, $1910=$ C. insularis Weise, 1910 syn. nov. Lectotypes are designated for C. gregaria Weise, 1910, C. insularis Weise, 1910, C. similis Weise, 1910 and C. tantilla Weise, 1910. A key to all the species is presented. Line drawings of male and female genitalia of all the species are included. Ecological and brief zoogeographical data on some species are given.
\end{abstract}

\section{INTRODUCTION}

The first records of Chaetocnema Stephens, 1831 in Madagascar are those of Baly (1877) and Harold (1879), who described C. madagascariensis and C. fraterna, respectively. About thirty years later, Weise (1910) made an important study of the leaf beetles of Madagascar and the Comoro Islands, and described five new species in this genus (C. consobrina, C. gregaria, C. insularis, $C$. tantilla and $C$. similis). As part of his study on the Madagascar leaf beetle fauna, Bechyné $(1948,1964)$ described additional species of Chaetocnema (alaotrensis, basipunctata, coronilla, monomorpha, pauliani and sylvia). Finally, additional data on some Chaetocnema species occurring in Madagascar were reported by Scherer (1962a).

In the present paper all Chaetocnema species known from Madagascar are critically revised. Some species are reported for the first time and others synonymized. Moreover, four new species are described (C. cachani, $C$. hygrophila, C. malgascia and $C$. orophila). For each taxon, type material was examined. Finally, the distributional data are updated, taxonomy discussed, male and female genitalia described, and ecological information given. The Madagascar locality names used in this paper, follow those of Viette (1991).

Abbreviations. LAED: length of median lobe of aedeagus; LAN: length of antennae; LB: total length of body; LE: length of elytra; LP: length of pronotum; LSP: length of spermatheca; WE: width of elytra; WP: width of pronotum. BAQ: Collection of the author, Dipartimento di Scienze Ambientali, University of L'Aquila, Italy; BMNH: The Natural History Museum, London, United Kingdom; CIRAD: Entomological collections of the "Centre de coop,ration internationale en recherche agronomique pour le développement", Montpellier, France; KSBS: State Biological Survey of Kansas, University of
Kansas, Lawrence, Kansas, USA; MNHN: Muséum National d'Histoire Naturelle, Paris, France; MRAC: Musée Royal de l'Afrique Centrale, Tervuren, Belgium; MZUF: Museo Zoologico "La Specola", Florence, Italy; NHMB: Naturhistorisches Museum, Basel, Switzerland; ZMHB: Museum für Naturkunde der HumboldtUniversität, Berlin, Germany.

\section{KEY TO SPECIES}

1 Elytral punctules only at base. Median lobe of aedeagus with wide and clearly visible ventral sulcus; apex with evident subtruncate small median tooth (Fig. 16). Basal part of spermatheca elongate, basally curved; ductus with two coils (Fig. 37). . . . . . . . C. basipunctata Bechyné, 1964 Elytral punctules over entire surface. ........... 2

2 Interantennal space clearly punctate in middle. ...... 5 Interantennal space not punctate in middle. ....... 3

3 Frontal carina narrow and moderately raised. Interantennal space clearly narrower than length of 1 st antennomere. ...

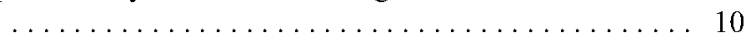
Frontal carina wide and not raised. Interantennal space about as wide as length of 1 st antennomere. ....... 4

4 Pronotum more finely punctate on disc, but basally with an evident line of well impressed punctules. Basal part of spermatheca elongate (Figs 28-34). . . . . . . . 14 - Pronotum strongly punctulate over entire surface. Basal part of spermatheca subglobose (Figs 25-27). ........ 19

5 Femora and 1st antennomere distinctly blackened. Dorsal integument blackish with a metallic cupreous reflection. Median lobe of aedeagus (Fig. 20) similar to C. pauliani (Fig. 19) but its apex is differently shaped. Female unknown. ................. C. hygrophila n. sp. Anterior and middle femora, and 1st antennomere pale. Dorsal integument generally has metallic greenish reflection. . ................... 6

6 Body shape elongate-elliptical. Pronotal surface rather smooth. Size generally large $(1.45<\mathrm{LE}<1.70 \mathrm{~mm}) . \quad \ldots 7$ 
- Body shape less elongate (oval in C. consobrina and C. ganganensis; elliptical in C. pauliani). Pronotal surface normally clearly microreticulate (sometimes almost smooth in C. ganganensis, but body shape thickset-oval). Size generally small $(1.10<\mathrm{LE}<1.60 \mathrm{~mm}) . \ldots \ldots \ldots \ldots \ldots$

7 Pronotum subtrapezoidal, laterally slightly rounded and convergent from base to apex. Elytral integument generally with metallic bright green or golden green reflection. Median lobe of aedeagus apically incised medially at apex and has distinct oblique striations on ventral surface (Fig. 17). Basal part of spermatheca relatively more elongate; ductus with 1 coil (Fig. 38). ... . C. wollastoni Baly, 1877

- Pronotum subrectangular, laterally rounded. Elytral integument generally with darker metallic reflection. Median lobe of aedeagus apically subrectangular with a smooth ventral surface (Fig. 14). Basal part of spermatheca relatively less elongate; ductus with 2 coils (Fig. 35).

C. bamakoensis Bechyné, 1955

8 Pronotum and vertex of head weakly punctate. Lateral elytral interstriae flat. Median lobe of aedeagus has a small truncate tooth at apex; ventral sulcus barely visible; dorsal sulcus with horizontal striation on apical half (Fig. 15). Basal part of spermatheca elongate; ductus with at least two coils (Fig. 36). . . . . . . . . . C. consobrina Weise, 1910

- Pronotum and vertex of head coarsely punctate. Lateral elytral interstriae convex, often subcarinate. ......... 9

9 Body shape elliptical with elytra little wider than pronotum. Pronotal surface generally clearly microreticulate. Male with 1 st anterior and middle tarsomere strongly dilated, heart-shaped. Median lobe of aedeagus slender, apically lanceolate; ventral sulcus evident from apex to base (Fig. 19). Spermatheca with ductus uncoiled (Fig. 40).

C. pauliani Bechyné, 1964

Body shape oval with elytra distinctly wider than pronotum. Pronotal surface generally weakly or very weakly microreticulate. Male with 1st anterior and middle tarsomere moderately dilated, subtriangular. Median lobe of aedeagus thickset, apically widely rounded; ventral sulcus only evident in apical half (Fig. 18). Spermatheca with ductus coiled (Fig. 39). . . . . . . . . . C. ganganensis Bechyné, 1955

10 Pronotal base distinctly and deeply bordered with an evident line of well impressed punctulation. Body shape relatively thickset. Pronotal surface almost smooth. Interocular space not punctate, with weakly shagreened surface. Median lobe of aedeagus strongly narrowed in apical third; in lateral view almost straight but apically strongly sinuous (Fig. 6). Ductus spermathecae with 4 or more coils (Fig. 28 ).

C. pulla Chapuis, 1879

Pronotal base finely bordered without line of punctules Body shape distinctly more elongate. Pronotal surface clearly microreticulate. Interocular space generally punctate with clearly shagreened surface. Median lobe of aedeagus not narrowed in apical third; in lateral view more or less curved and apically not strongly sinuous (Figs 1-3). Ductus spermathecae uncoiled or at maximum with 2 coils (Figs 21-24). ..................... 11

11 Elytral interstriae flat on disc, not or very weakly punctate. Elytra entirely black with weak metallic dark green reflection or with more or less large reddish brown spots. . . . 12

- Elytral interstriae convex on disc, distinctly punctate. Elytra black; always uniformly coloured, generally with bright green or bronze metallic reflection. . . . . . . . . . 13
12 Size small (LE $<1.60 \mathrm{~mm}$ ). Elytra usually at least partially reddish brown. 1st antennomere, tibiae and tarsi entirely pale. Anterior angles of pronotum weakly thickset, apically acute. Male with 1st anterior and middle tarsomere slightly dilated. Median lobe of aedeagus slender; in ventral view laterally subparallel; ventral sulcus little visible in distal half; dorsal sulcus clearly visible in distal half (Fig. 1). Ductus spermathecae with one or two coils (Fig. 21).

C. bilunulata Demaison, 1902

- Size large (LE > $1.60 \mathrm{~mm}$ ). Elytra entirely black with weak greenish metallic reflection. 1st antennomere, tibiae and tarsi at least partially darkened. Anterior angles of pronotum more strongly thickset, apically rounded. Male with 1st anterior and middle tarsomere strongly dilated. Median lobe of aedeagus elongate, apically obtusely rounded; ventral sulcus not visible (Fig. 3). Ductus spermathecae uncoiled (Fig. 23). . . . . . . . . . . C. picipes Stephens, 1831

13 Distal half of antennae distinctly darkened. Elytra comparatively long (generally LE/LP > 2.95). Elytral interstriae more densely punctate. Elytral integument with bright metallic golden green reflection. Interocular space more diffusely and strongly punctate. Size generally large (LE > $1.33 \mathrm{~mm}$ ). Median lobe of aedeagus slender; in ventral view laterally subparallel, apically lanceolate; ventral sulcus absent (Fig. 2). Basal part of spermatheca elongate (Fig. 22).

C. malgascia $\mathrm{n}$. $\mathrm{sp}$.

- Antennae mostly or entirely pale. Elytra comparatively short (generally LE/LP < 2.95). Elytral interstriae with a single line of punctules. Elytral integument with metallic dark green reflection. Interocular space more sparsely and finely punctate. Size generally smaller ( $\mathrm{LE}<1.33 \mathrm{~mm}$ ). Basal part of spermatheca subglobose (Fig. 24). Only parthenogenetic females are known in the Afrotropical Region.

.................. C. confinis Crotch, 1873

14 Pronotum and head with clearly impressed punctation. Median lobe of aedeagus (Fig. 11) in ventral view wider in middle and apically acute; in lateral view weakly curved. Basal part of spermatheca subcylindrical; ductus with 2 or 3 coils (Fig. 32) . . . . . . . . . . . C. vadoni Bechyné, 1948 Pronotum and head finely or very finely punctate. . . . 15

15 Pronotum generally more transverse (WP/LP: $\delta>1.58$; $q$ $>1.60$ ) or anteriorly weakly narrowed. Head sparsely punctulate, weakly impressed on vertex. Size generally small $(\mathrm{LE}<1.45 \mathrm{~mm})$. Median lobe of aedeagus in ventral view laterally subparallel and apically lanceolate (Fig. 12). Spermatheca small (LSP $<0.20 \mathrm{~mm}$ ), with basal part larger in distal half; ductus with 1 coil (Fig. 33). . C. orophila n. sp. Pronotum usually less transverse (WP/LP: $\delta<1.58$; $q$ $<1.60$ ) or anteriorly strongly narrowed. Head with punctation generally denser and clearly impressed on vertex. Size generally large $(\mathrm{LE}>1.45 \mathrm{~mm})$. Spermatheca large (LSP > $0.20 \mathrm{~mm}$ ), with basal part wider near ductus insertion; ductus normally uncoiled or with 2 or 3 coils (Figs 29, 30,

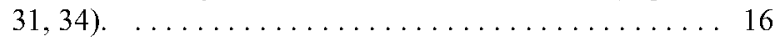

16 Pronotum laterally almost straight or very weakly rounded, basally about as wide as apically. Body shape elongate. Dorsal integument with marked bronze metallic reflection.

Pronotum laterally rounded, apically narrower than basally. Body shape thickset. Dorsal integument with slight metallic reflection. $\ldots \ldots \ldots \ldots \ldots \ldots \ldots \ldots \ldots \ldots \ldots$ 
17 Pronotal base distinctly bordered. Pronotum subrectangular. Elytra laterally subparallel. Anterior angles of pronotum more raised. Median lobe of aedeagus with dorsal sulcus basally narrowed (Fig. 8); in lateral view bent in apical third. Spermatheca with ductus elongate and coiled. (Fig. $30)$. ................ C. madagascariensis Baly, 1877 Pronotal base finely bordered. Pronotum subtrapezoidal, slightly wider at base. Elytra laterally gradually narrow from basal third to apex. Anterior angles of pronotum less raised. Median lobe of aedeagus with dorsal sulcus wide basally; in lateral view straight in apical third (Fig. 7). Spermatheca with short and uncoiled ductus (Fig. 29). ........

C. cachani $\mathrm{n} . \mathrm{sp}$

18 Head with vertex impunctate. Body shape oval with pronotum anteriorly more strongly narrowed. Anterior and middle femora reddish; last antennomeres usually not obscured. Median lobe of aedeagus more slender, with acute apical part; in lateral view decisively curved (Fig. 13). Basa part of spermatheca comparatively thickset; ductus with 4 or more coils (Fig. 34). . . . . . . . C. similis Weise, 1910 Vertex of head with dense fine punctulation. Body shape elliptical with pronotum anteriorly more weakly narrowed. Anterior and middle femora almost entirely black; last antennomeres usually obscured. Median lobe of aedeagus less slender, with rounded apical part; in lateral view almost straight (Figs 9-10). Basal part of spermatheca comparatively elongate; ductus with 2 or 3 coils (Fig. 31). . . . . . .

................... . gregaria Weise, 1910

19 Interocular space with some large and well impressed punctules. Body shape comparatively more elongate (LE/LP > 2.85). Elytral interstriae convex. Median lobe of aedeagus comparatively more thickset; in lateral view apically less sinuous (Fig. 4). Ductus spermathecae laterally inserted (Figs 25-26). . . . . . . . . . C. coronilla Bechyné, 1964 Interocular space without large punctules but distinctly shagreened. Body shape comparatively more thickset (LE/LP < 2.85). Elytral interstriae usually flat. Median lobe of aedeagus comparatively more slender; in lateral view apically distinctly sinuous (Fig. 5). Ductus spermathecae medially inserted (Fig. 27). . . . C. C. fuscipennis Scherer, 1962b

\section{Chaetocnema bamakoensis Bechyné}

Chaetocnema bamakoensis Bechyné, 1955: 548-549

Chaetocnema katangana Bechyné, 1960: 26 (synonymized by Scherer, 1962b: 48)

Chaetocnema monomorpha Bechyné: sensu Scherer, 1962a: 65 (misidentification)

Material examined. Madagascar: Bekily [24.14S 45.18E], iv.1942, leg. A. Seyrig, 1 ex. (MRAC); Southern Madagascar, forest $\mathrm{N}$ of Tôlanäro [24.58S 46.59E], 1900, leg. C. Alluaud, 1 ex. (MNHN); Central-Southern Madagascar, 1901, leg. C. Alluaud, 2 exx. (MNHN).

Distribution. Mali, Nigeria, Ivory Coast, Chad, Sudan, Ethiopia and Democratic Republic of Congo (Scherer, 1959, 1972; Tiberghien, 1976); Sierra Leone, Uganda and Kenya (personal data). First record for Madagascar.

Bionomics. Species found in moist environments associated with Gramineae, Cyperaceae and Marantaceae (Thalia sp.) (Tiberghien, 1976).

\section{Chaetocnema basipunctata Bechyné}

Chaetocnema basipunctata Bechyné, 1964: 155

Material examined. Madagascar: "Tananarive" [= Antananarivo: $18.54 \mathrm{~S} 47.29 \mathrm{E}$ ], holotype ( ${ }^{\top} \mathrm{NHMB}$ : Coll. Frey); Antananarivo [18.54S 47.29E], yellow pan traps, leg. R.W. Brooks, 9 exx. (KSBS); Antananarivo, Parc of Tsimbazaza [18.55S 47.31E], 26-31.x.1984, yellow pan traps, leg. R.W. Brooks, 16 exx. (KSBS).

Distribution. Madagascar.

Bionomics. No ecological information is available for this species.

Comments. C. basipunctata is the most uncertain species of Chaetocnema occurring in Madagascar. Its systematic affinities are unknown because it shares morphological characters with several species-groups. For example, on the basis of the presence of a narrow frontal carina, especially in the male, $C$. basipunctata is similar to the species in the subgenus Tlanoma Motschulsky, 1845 (represented in Madagascar by the species bilumulata, confinis, picipes, malgascia n.sp. and pulla); on the basis of the line of well impressed punctules present on the pronotal base and the very weak punctation on the vertex of the head this species is similar to species of the gregaria species-group (represented in the Madagascar fauna by the species gregaria, cachani n.sp., madagascariensis, orophila n.sp., and vadoni); finally on the basis of the shape of the male and female genitalia (Figs 16, 37 ) it shows clear affinities with the Afrotropical species such as C. kibonotensis Weise, 1910 widespread in Central and Southern Africa (personal data), or Asiatic species related to C. hortensis (Geoffroy, 1785).

\section{Chaetocnema bilunulata Demaison}

Chaetocnema bilunulata Demaison, 1902: 24-25

Chaetocnema vincenti Reitter, 1906: 37 (synonymized by Pic, 1909: 138)

Chaetocnema bilunulata Demaison var. praescutellaris Pic, 1911: 10

Chaetocnema diluta Laboissière, 1942: 85-86 (synonymized by Scherer, 1962b)

Chaetocnema sylvia Bechyné, 1964: 157-158 syn. nov.

Material examined. Madagascar: "Boeny Maevatanana" [13.52S 48.32E], "xi.1899, leg. J. Decorse", 1 ex. (paratype of C. sylvia) (MNHN); "Toamasina" [18.08S 49.24E], 1 ex. (paratype of C. sylvia) (NHMB: Coll. Frey); "Antsingy de Bekopaka" [19.08S 44.47E], "forêt", vii.1949, leg. R. Paulian, 1 ex. (allotype of C. sylvia) (MNHN) and 2 exx. (paratypes of $C$. sylvia) (NHMB: coll. Frey); Ihosy [22.23S 46.07E], 1901, leg. C. Alluaud, 1 ex. (MNHN); Southern Madagascar, pays Androy (North) [24.20S 45.06E], 1900, leg. C. Alluaud, 2 exx. (MNHN); Toliara Province, W of Tôlanäro [25.01S 46.39E], 45 m, 15.xi.1994, at light, leg. M.A. Ivie - D.A. Pollock, 1 ex. (KSBS); Toliara Province, $\mathrm{N}$ of Ambovombe [25.06S 45.60E], 157 m, 14.xi.1994, small pond, leg. M.A. Ivie - D.A. Pollock, 1 ex. (KSBS).

Distribution. Egypt, Chad, Sudan, Democratic Republic of Congo (Scherer, 1972), Madagascar, Namibia, Republic of South Africa and Swaziland (personal data).

Bionomics. Species associated with Gramineae in open fields (cf. Scherer, 1962b; Tiberghien, 1976). 


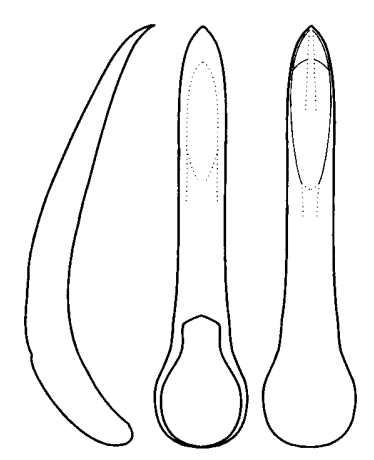

1

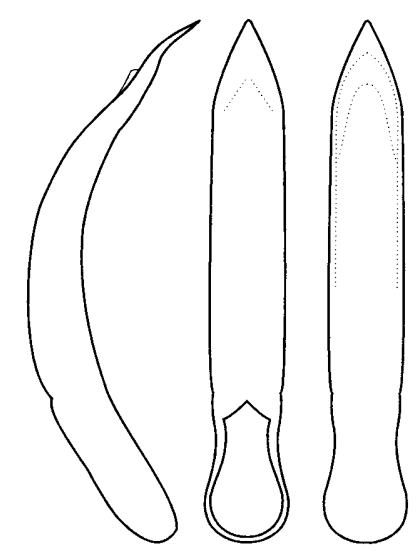

2

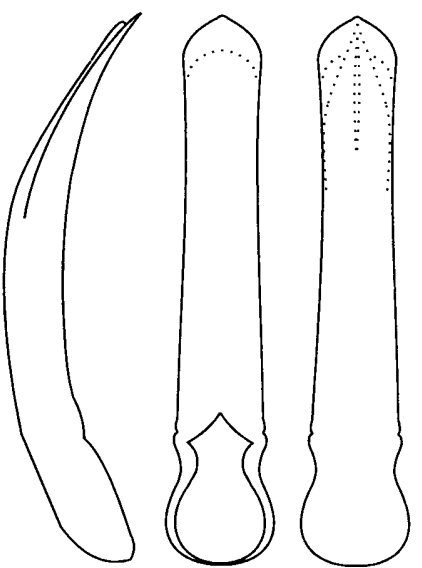

3
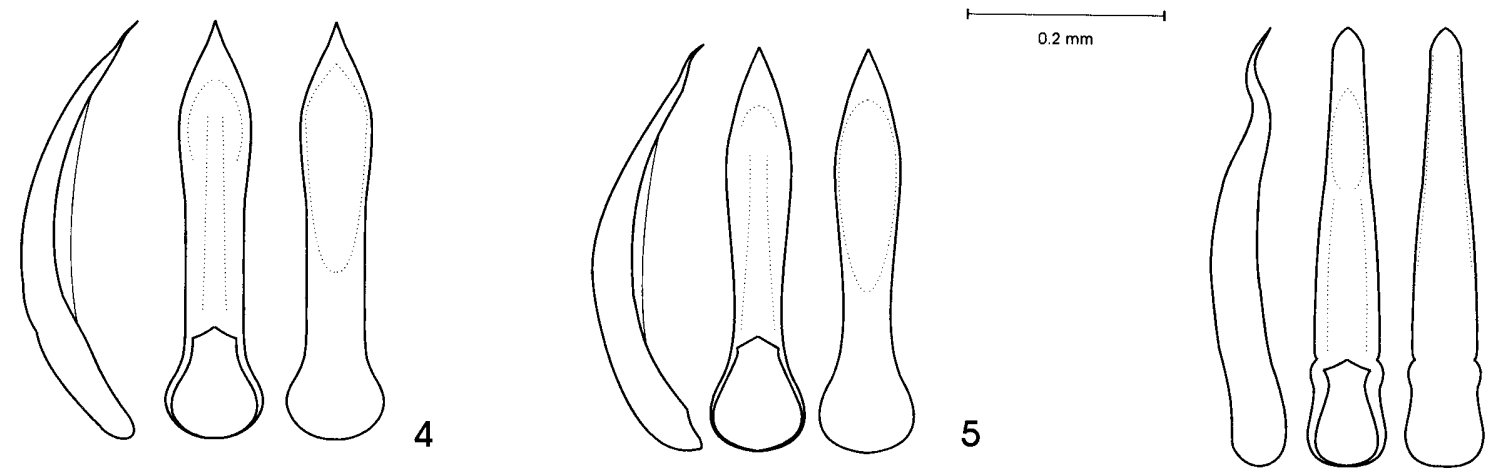

6

Figs 1-6. Lateral, ventral and dorsal view of the median lobe of the aedeagus in Chaetocnema species: C. bilunulata Demaison, Madagascar, Bekopaka (paratype of C. sylvia Bechyné) (1); C. malgascia n. sp., holotype (2); C. picipes Stephens, Italy, Lombardia (3); C. coronilla Bechyné, Madagascar, Ambohitantely, paratype (4); C. fuscipennis Scherer, Madagascar, Anjananaharibe (5); C. pulla Chapuis, Madagascar, Nosy-be (lectotype of C. tantilla Weise) (6).

Comments. In comparison with the specimens of $C$. bilunulata from Continental Africa, the specimens from Madagascar more frequently show uniform blackish colouration on the elytra.

\section{Chaetocnema cachani n. sp.}

Description. Holotype ( $\left.\delta^{\star}\right)$ : dorsal integument black with evident metallic cupreous reflection especially on pronotum. Body shape elongate-elliptical, convex (LB = $2.27 \mathrm{~mm}$ ). Maximum pronotal width at base: $0.97 \mathrm{~mm}$; maximum elytral width at basal third: $1.23 \mathrm{~mm}$.

Head diffusely but finely punctate, with clearly shagreened surface; frontal grooves finely but distinctly impressed; frontal tubercles absent; interantennal space wide; frontal carina wide and flat; labrum piceous, short, subrectangular, with six preapical setae; palpi piceous; antennae little longer than half body length (LAN/LB = 0.71 ); antennomeres 1-6 reddish, 7 weakly darkened; 8-11 brown; length of each antennal segment proportional to numerical sequence $14: 8: 10: 10: 10: 9: 11: 12: 12$ : 13:15.

Pronotum moderately transverse $(\mathrm{LP}=0.64 \mathrm{~mm}$; $\mathrm{WP} / \mathrm{LP}=1.49$ ), slightly wider at base, laterally almost straight; lateral and basal margin very distinctly bordered; anterior angles thickset, apically rounded, with a small setigerous pore; punctation very weakly impressed on clearly microreticulate surface; pronotal base with an evident line of punctules.

Elytra elongate $(\mathrm{LE}=1.65 \mathrm{~mm} ; \mathrm{LE} / \mathrm{LP}=2.53)$, entirely covering pygidium; laterally weakly rounded; punctation arranged in 9 regular rows $(+1$ scutellar interrupted at basal half); punctulation well impressed on disc but more weakly on apical declivity; interstriae flat with very fine punctation; humeral callus present; macropterous. Scutellum semi-circular, with shagreened surface.

Hind femora dark brown; anterior and middle femora partially darkened; tibiae and tarsi reddish; hind tibiae with lateral dilation acute and apical spur short and reddish; 1st anterior and middle tarsomere very weakly dilated, subtriangular.

Ventral part dark brown with weak metallic reflection. Last sternite with sparse punctules on an almost smooth surface; special preapical impressions absent.

Median lobe of aedeagus (Fig. 7) slender (LAED = $0.85 \mathrm{~mm}$; LE/LAED = 1.94); in ventral view laterally subparallel; apical part rounded, medially with a small tooth; ventral sulcus slightly visible; dorsal sulcus evident in apical third; dorsal ligula subtriangular with base apically turned; median lobe in lateral view almost straight with ventrally bent apex.

Paratypes: $\delta: \mathrm{LB}=2.16 \pm 0.10 \mathrm{~mm} ; \mathrm{LAN}=1.61 \pm$ $0.04 \mathrm{~mm} ; \mathrm{LP}=0.62 \pm 0.03 \mathrm{~mm} ; \mathrm{WP}=0.94 \pm 0.03 \mathrm{~mm}$; $\mathrm{LE}=1.60 \pm 0.05 \mathrm{~mm} ; \mathrm{WE}=1.18 \pm 0.04 \mathrm{~mm} ; \mathrm{LAED}=$ 

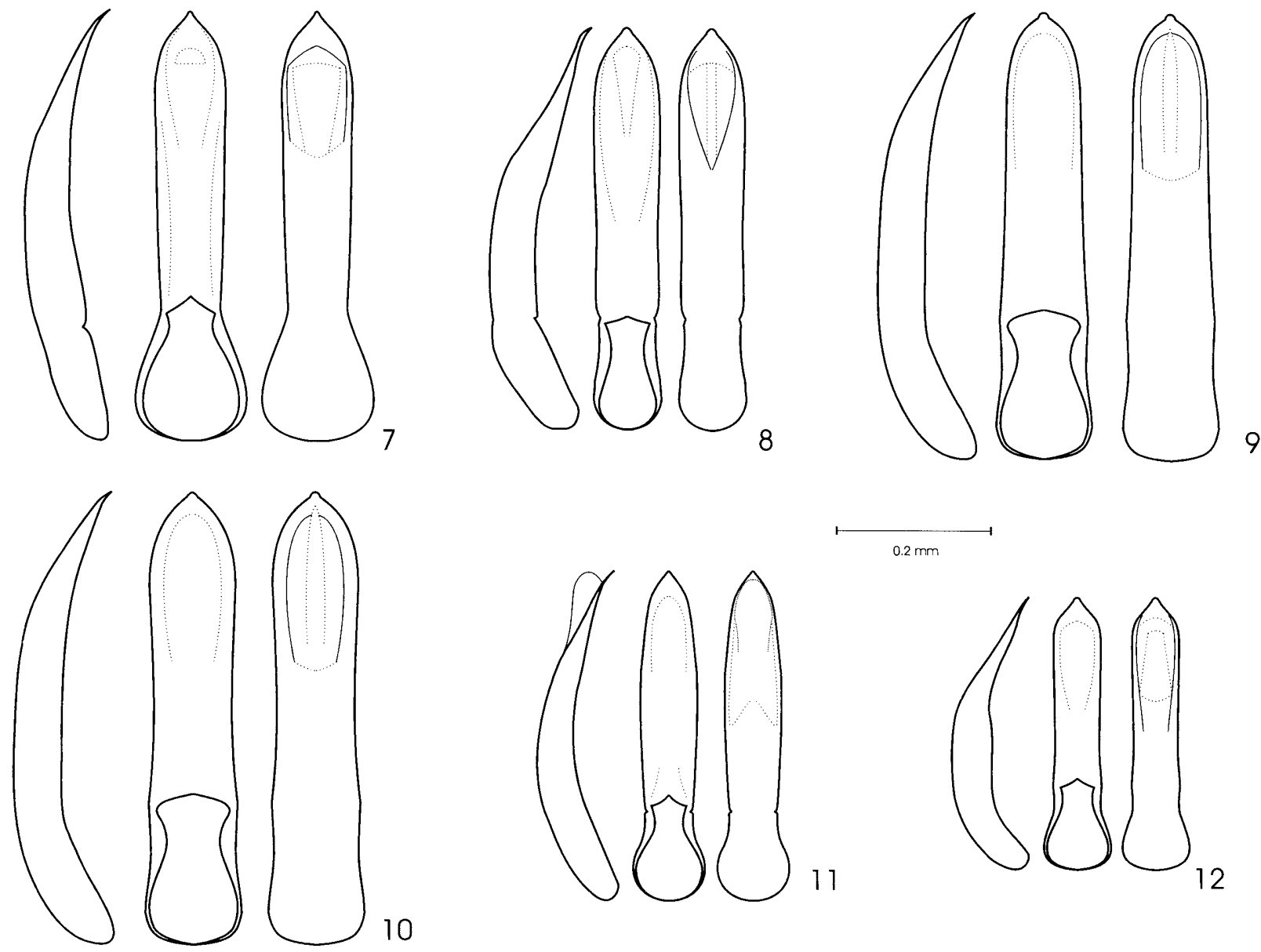

11

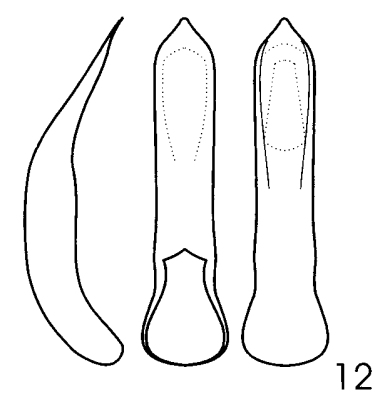

10

Figs 7-12. Lateral, ventral and dorsal view of the median lobe of the aedeagus in Chaetocnema species: C. cachani n. sp., holotype (7); C. madagascariensis Baly, Madagascar, Tananarive (8); C. gregaria Weise, lectotype (9) and Madagascar, Antanambe (10); C. vadoni Bechyné, Madagascar, Andapa, paratype (11); C. orophila n. sp., holotype (12).

$0.83 \pm 0.02 \mathrm{~mm} ; \mathrm{LAN} / \mathrm{LB}=0.75 \pm 0.04 ; \mathrm{WP} / \mathrm{LP}=1.53 \pm$ $0.04 ; \mathrm{LE} / \mathrm{LP}=2.59 \pm 0.08 ; \mathrm{LE} / \mathrm{LAED}=1.92 \pm 0.02$. $\%$ : $\mathrm{LB}=2.51 \pm 0.12 \mathrm{~mm} ; \mathrm{LAN}=1.75 \pm 0.04 \mathrm{~mm} ; \mathrm{LP}=0.69$ $\pm 0.06 \mathrm{~mm} ; \mathrm{WP}=1.08 \pm 0.08 \mathrm{~mm} ; \mathrm{LE}=1.90 \pm 0.08 \mathrm{~mm}$; $\mathrm{WE}=1.35 \pm 0.08 \mathrm{~mm} ; \mathrm{LSP}=0.24 \pm 0.01 \mathrm{~mm} ; \mathrm{LAN} / \mathrm{LB}$ $=0.70 \pm 0.02 ; \mathrm{WP} / \mathrm{LP}=1.56 \pm 0.02 ; \mathrm{LE} / \mathrm{LP}=2.75 \pm$ $0.13 ; \mathrm{LE} / \mathrm{LSP}=7.64 \pm 0.09$. Female generally bigger with slightly narrower anterior and middle tarsomere. Spermatheca (Fig. 29) with subcylindrical basal part and little elongate and uncoiled ductus. Paratypes chromatically and sculpturally very similar to the holotype, sometimes dorsal integument with more evident bronze reflection or with subconvex elytral interstriae.

Diagnosis. This species is externally very similar to $C$. madagascariensis but it is easily distinguishable mainly by: pronotum subtrapezoidal (subrectangular in C. madagascariensis); pronotal base finely bordered (distinctly bordered in $C$. madagascariensis); pronotal anterior angles more raised (less raised in C. madagascariensis); elytra laterally subrounded (subparallel in C. madagascariensis); median lobe of aedeagus (Fig. 7) in lateral view straight in apical third [bent (Fig. 8) in C. madagascariensis]; ductus spermathecae (Fig. 29) short and uncoiled [elongate and coiled (Fig. 30) in C. madagascariensis].
Type material. Holotype $\delta^{\star}$, Madagascar: "Tananarive" $[=$ Antananarivo: 18.54S 47.29E], "1921, leg. R. Decary" (MNHN). Paratypes: same locality, date and collector of the holotype, 3 o and 1 \& (MNHN); "Station Manankazo" [18.09S 47.11E], "km 130, prairie, bord d'eau, 6.ii.1948, leg. P. Cachan", 1 o and 1 o (NHMB: Coll. Frey); "Ambohitantely" [18.10S 47.17E], "lot. 1, 3, 4, 4.ii.1948, leg. P. Cachan", 3 o and 2 (NHMB: Coll. Frey).

Etymology. This species is named after Pierre Chachan (Paris), one of its collectors.

Distribution. Central Madagascar.

Bionomics. This species is found in moist environments ("prairie, bord d'eau" in Station Manankazo).

\section{Chaetocnema confinis Crotch}

Chaetocnema confinis Crotch, 1873: 75

Chaetocnema etiennei Jolivet, 1979: 641-642 (synonymized by Jolivet, 1998: 35-36)

Material examined. Comoro Islands: Anjouan, Col de Patsi [12.18S 43.42E], 6.xii.1983, leg. R. Jocque, 1 ex. (MRAC); Anjouan, Miringoni [12.16S 43.48E], 700 m, 6-12.xi.1983, leg. R. Jocque, 4 exx. (MRAC). Madagascar: Ranomafana [21.15S 47.26E], 14.iv.1992, local collectors, 1 ex. (BAQ); Toliara Province, Bezi Mahafaly Reserve [23.42S 44.42E], 19.xi.1984, malaise trap, leg. R.W. Brooks, 1 ex. (KSBS). 

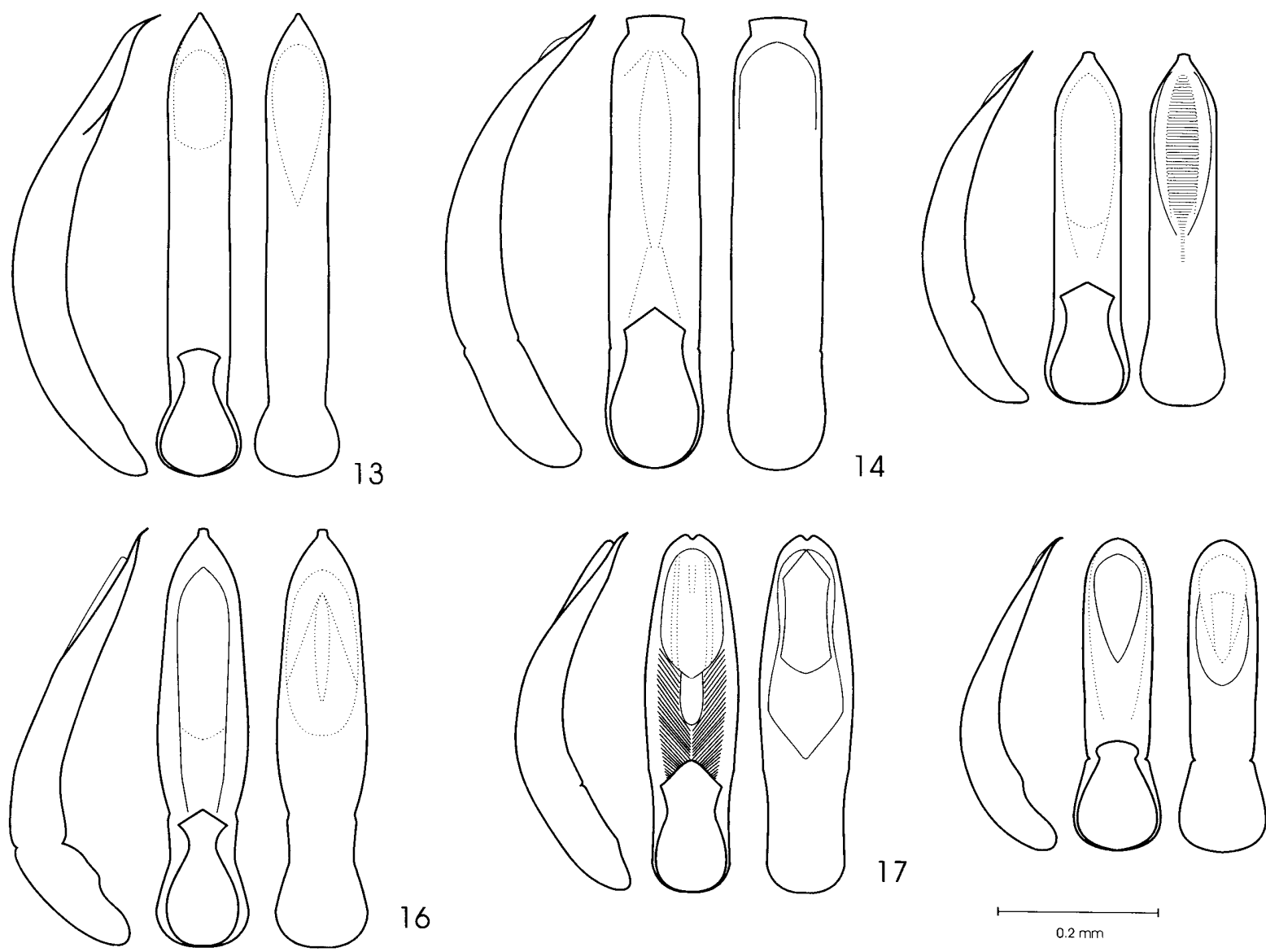

16

17

Figs 13-18. Lateral, ventral and dorsal view of the median lobe of the aedeagus in Chaetocnema species: C. similis Weise, lectotype (13); C. bamakoensis Bechyné, Madagascar, Tôlanäro (14); C. consobrina Weise, Madagascar, Baie d'Antogil (15); C. basipunctata Bechyné, Madagascar, Tananarive (16); C. wollastoni Baly, Madagascar, Tananarive (17); C. ganganensis Bechyné, Madagascar, Andevoranto (18).

Distribution. Because of the widespread cultivation of sweet potato, this Nearctic species is now widespread in Oriental Asia, in many islands of the Indian and Pacific Oceans and in Contiental Africa. (Jolivet, 1998; personal data). This species spreads through wind dispersal of parthenogenetic females (cf. Jolivet, 1998).

Bionomics. Species associated with Convolvulaceae in particular the genus Ipomoea [I. aquatica Forsk. and I. batatas (L.) Lam.] (cf. Jolivet, 1998).

\section{Chaetocnema consobrina Weise}

Chaetocnema consobrina Weise, 1910: 436

Chaetocnema consobrina Weise: Scherer, 1962a: 65

Material examined. Comoro Islands: Mayotte, Chingoni [12.48S 45.08E], $70 \mathrm{~m}$, x.1958, leg. E. Raharizonina, 1 ex (MNHN). Madagascar: "NW-Madagascar, J. Nossibé" [Nosy-be:13.20S 48.16E], "1.xi.1895, leg. S. Voeltzkow", type of (ZMHB); Maroantsetra Region [15.25S 49.47E], leg. J. Vadon, 1 ex. (MNHN); Eastern Madagascar, Ankalampona [15.25S 49.50E], $130 \mathrm{~m}$, Navana-Maroantsetra, iii.1958, leg. P. Soga - E. Raharizonina, 1 ex. (MNHN); Andranofotsy [15.26S 49.49E], 5.iv.1938, leg. J. Vadon, 3 exx. (MRAC; NHMB: coll. Frey) (cf. Scherer, 1962a); Eastern Madagascar, Baie d'Antogil - Fampanambo [15.27S 49.42E], floods, xii.1958, leg. J. Vadon, 1 ex. (MRAC); Amparafaravola [17.45S 48.12E], W of Lac Alaotra, 1921, leg. R. Decary, 1 ex. (ex paratype of $C$. alaotrensis Bechyné) (MNHN); Toamasina [18.08S 49.24E], ii.1935, 2 exx. (NHMB: Coll. Frey); Antananarivo [18.54S 47.29E], 1921, leg. R. Decary, 1 ex. (MNHN); Antananarivo [18.54S 47.29E], yellow pan traps, leg. R.W. Brooks, 1 ex. (KSBS); Antananarivo, Parc of Tsimbazaza [18.55S 47.31E], 26-31.x.1984, yellow pan traps, leg. R.W. Brooks, 1 ex. (KSBS); Périnet [18.57S 48.30E], 1 ex. (MNHN).

Distribution. Northern and Central Madagascar, Comoro Islands.

Bionomics. Species found in moist environments ("floods"; some specimens collected together with $C$. pauliani).

\section{Chaetocnema coronilla Bechyné}

Chaetocnema coronilla Bechyné, 1964: 157.

Material examined. Madagascar: "Ambohitantely" [18.10S 47.17E], "dans depression humide, km 192 route Ankazobe, 26.ii.1948, leg. P. Cachan.", allotype $+(\mathrm{MNHN})$ and 3 paratypes (NHMB: Coll. Frey); Antananarivo [18.54S 47.29E], 1921, leg. R. Decary, 4 exx. (MNHN); Tsinjoarivo [19.39S 47.41E], xi.1953, leg. R. Paulian, 1 ex. (MNHN).

Distribution. Central Madagascar.

Bionomics. Species found in moist environments ("dans depression humide" in Ambohitantely).

Comments. This species is closely related to C. fuscipennis with which it shares the same external habitus, and aedeagal and spermathecal shape. However, C. coronilla is easily distinguishable by the presence of some coarse 


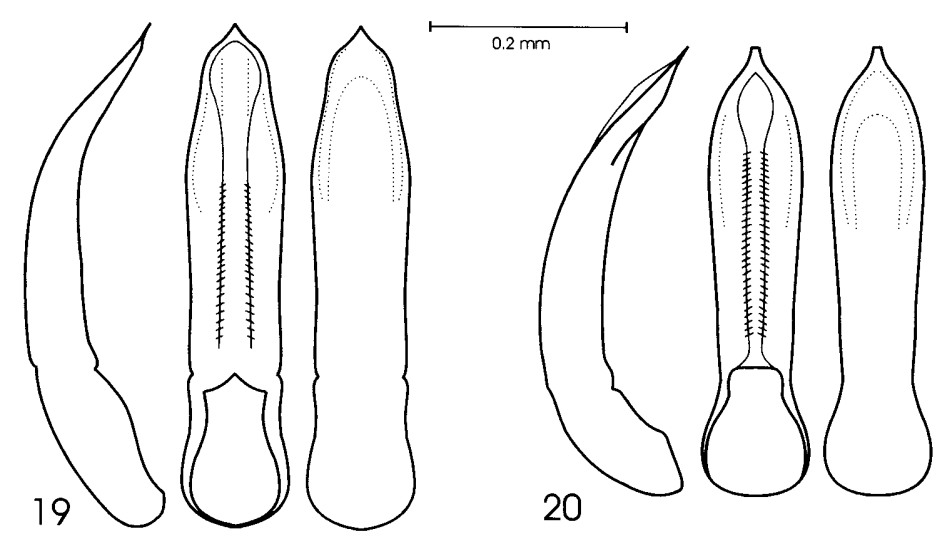

Figs 19-20. Median lobe of aedeagus in lateral, ventral and dorsal view in Chaetocnema species.: C. pauliani Bechyné, Madagascar, Tananarive (19); C. hygrophila n. sp., holotype (20).

punctules clearly impressed on the interocular space, the more elongate body shape, the wider pronotum, and the less acute lateral dilation of hind tibiae.

\section{Chaetocnema fuscipennis Scherer}

Chaetocnema fuscipennis Scherer, 1962b: 41-43

Material examined. Madagascar: Eastern Madagascar, Marojejy, N of Anjanaharibe [14.44S 49.27E], 1750 m, ii.1961, leg. P. Soga, 1 ex. (MNHN).

Distribution. Democratic Republic of Congo and Congo (Scherer, 1962b); Sierra Leone (personal data). First record for Madagascar.

Bionomics. Species found in moist environments probably associated with Gramineae (cf. Scherer, 1962b).

\section{Chaetocnema ganganensis Bechyné}

Chaetocnema ganganensis Bechyné, 1955: 548.

Material examined. Madagascar: Northern Madagascar, Antsira(nana District, Analamerana [12.40S 49.32E], $80 \mathrm{~m}, 50 \mathrm{~km}$ SE Antsiranana, i.1959, leg. R. Andria, 10 exx. (MNHN); Nosy-be, Djamandjary [13.21S 48.12E], 4.i.1987, leg. F. Faraci 1 ex. (MZUF); Eastern Madagascar, Baie d'AntogilFampanambo [15.27S 49.42E], floods, xii.1958, leg. J. Vadon, 1 ex. (MRAC); Antananarivo, Tsimbazaza [18.55S 47.31E], i.1952, leg. R. Benoist, 1 ex. (NHMB: Coll. Frey) (Scherer, 1962a: reported as C. pauliani); Andevoranto [18.57S 49.06E], 1 ex. (MNHN); Southern Madagascar, 1901, leg. C. Alluaud, 1 ex. (MNHN).

Distribution. Guinea, Sierra Leone, Ivory Coast (Scherer, 1969; Biondi, 1994); Algeria, Mali, Nigeria, Namibia, Republic of South Africa, Zimbabwe (personal data). First records for Madagascar.

Bionomics. No ecological information is available for this species, but probably lives in moist environments ("floods" in Baie d'Antogil-Fampanambo).

Comments. Relative to the populations of $C$. ganganensis occurring in Continental Africa, the Madagascar specimens have no or only weak microretuiculation on the pronotal surface. Moreover, this species is very similar to C. sundara Maulik, 1931 from the Seychelles, from which it is distinguished by having more convex lateral elytral interstriae, more rugose punctation on the head and pronotum and a more strongly curved median lobe of aedeagus in lateral view.

\section{Chaetocnema gregaria Weise}

Chaetocnema gregaria Weise, 1910: 435

Chaetocnema insularis Weise, 1910: 436 syn. nov.

Chaetocnema gregaria Weise: Scherer, 1962a: 65

Chaetocnema gregaria Weise: Bechyné, 1964: 158

Lectotype Designation: The designation of the lectotypes of $C$. gregaria Weise and $C$. insularis Weise are necessary because the original descriptions of these species were based on several syntypes from different localities. C. gregaria: lectotype $\widehat{\delta}$ "NW-Madagascar, J. Nossibé, 8.xi.1895, leg. S. Voeltzkow”, M. Biondi des. (ZMHB); C. insularis, lectotype o, "Cap Sainte Marie, viii.1904, streifsack, leg. S. Voeltskow”, M. Biondi des. (ZMHB) .

Material examined. Madagascar: "NW-Madagascar, J. Nossibé" [Nosy-be:13.20S 48.16E], "8.xi.1895, leg. S. Voeltzkow", lectotype $\delta$ and 2 paralectotypes (ZMHB); ditto, 1.xi.1895, 1 paralectotype (ZMHB); ditto, 5.xi.1895, 1 paralectotype (ZMHB); Analalava Province, Maromandia [14.12S 48.05E], 1923, leg. R. Decary, 2 exx. (MNHN); Eastern Madagascar, Maroantsetra District, Antakotako [15.18S 49.48E], leg. J. Vadon - A. Peyrieras, 4 exx.; ditto, viii.1938, leg. J. Vadon, 1 ex. (det. by Bechyné as C. madagascariensis Baly) (MNHN): Maroantsetra Region [15.25S 49.47E], vii.1936, leg. J. Vadon, 1 ex. (MNHN); Maroantsetra [15.26S 49.44E], 1935, leg. R. Heim, 2 exx. (MNHN); Andranofotsy [15.26S 49.42E], 5.iv.1938, leg. J. Vadon, 2 ex. (MRAC; NHMB: Coll. Frey) (cf. Scherer, 1962a); Eastern Madagascar, N of Mananara, Antanambe [16.26S 49.50E], leg. J. Vadon - A. Peyrieras, 5 exx. (MNHN); "Fénérive" [= Fenoarivo - Atsinanana: 17.22S 49.24E], "vii.1904, leg. S. Voeltzkow", paralectotype of $C$. insularis (ZMHB); Antananarivo [18.54S 47.29E], 1921, leg. R. Decary, 3 exx. (MNHN); Vatomandry [19.20S 48.57E], leg. J. Vadon, 1 ex. (MNHN); Mandritsara [19.32S 47.03E], xii.1937, leg. J. Vadon, 1 ex. (MNHN); Eastern Coast, forest, 1901, leg. C. Alluaud, 2 exx. (MNHN); Madagascar, int. austr., leg. S. Hildebrandt leg., 1 ex. (ZMHB); Southern Madagascar, pays Androy (North) [24.20S 45.06E], 1900, leg. C. Alluaud, 1 ex. (MNHN); Tôlanaro Province, Antanimora [24.49S 45.39E], 1926, leg. R. Decary, 1 ex. (MNHN); "Cap Sainte Marie" [= Tanjona Vohimena: 25.36S 45.10E], "viii.1904, streifsack, leg. S. Voeltskow", lectotype ô of C. insularis (ZMHB).

Distribution. Kenya (Patte Island) and Madagascar (Weise, 1910); Republic of South Africa (personal data). 


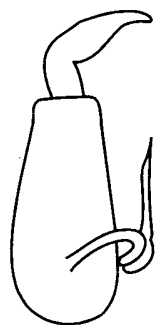

21

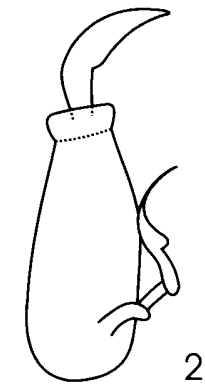

22

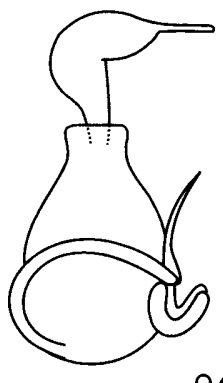

26

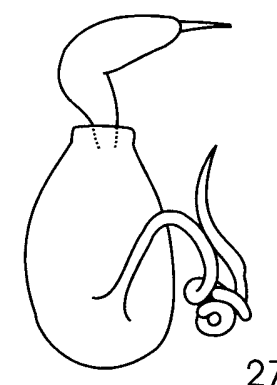

27
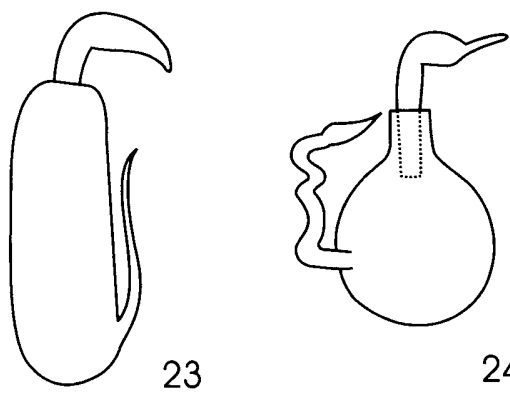

24

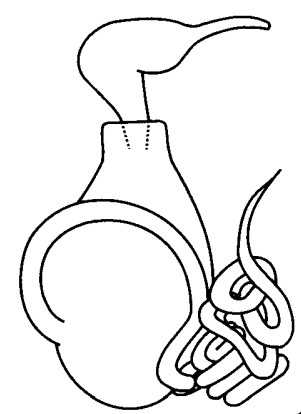

25

28
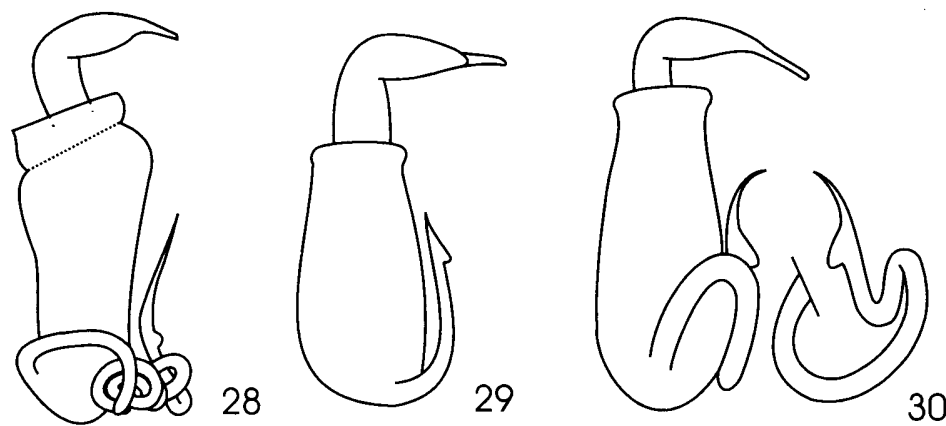

Figs 21-30. Spermatheca in Chaetocnema species.: C. bilunulata Demaison, Madagascar, Ihosy (21); C. malgascia n. sp., Madagascar, Soavina, paratype (22); C. picipes Stephens, Madagascar, Ranomafana env. (23); C. confinis Crotch, Madagascar, Toliaria (24); C. coronilla Bechyné, Madagascar, Ambohitantely, paratype (25) and Madagascar, Tananarive (26); C. fuscipennis Scherer, Sierra Leone, Freetown (27); C. pulla Chapuis, Eastern Madagascar (28); C. cachani n. sp., Madagascar, Ambohitantely, paratype (29); C. madagascariensis Baly, Madagascar, Tananarive (30).

Bionomics. No ecological information is available for this species.

Comments. Of the Madagascar Chaetocnema, C. gregaria is probably the most common. This taxon is very variable in size, in sculpture and in aedeagal shape (Figs 9-10). In the same species-group as C. gregaria, I include other Madagascar species such as $C$. madagascariensis, C. cachani n. sp., C. orophila n. sp., and C. vadoni, and also the African species related to $C$. nigripennis Laboissière, 1942.

\section{Chaetocnema hygrophila n. sp.}

Chaetocnema fraterna Harold: sensu Bechyné,1964: 157 (misidentification)

Description. Holotype ( $\delta)$ : dorsal integument black with an evident metallic cupreous reflection. Body shape elongate-elliptical, convex $(\mathrm{LB}=2.00 \mathrm{~mm})$. Maximum pronotal width at base: $0.85 \mathrm{~mm}$; maximum elytral width at basal third: $1.04 \mathrm{~mm}$.

Head with frons coarsely punctulate with weakly but distinctly shagreened surface; frontal grooves finely impressed; frontal tubercles absent; interantennal space wide without frontal carina; labrum piceous, short, subrectangular, with six preapical setae; palpi piceous; antennae about as long as half body length (LAN/LB = $0.56 \mathrm{~mm}$ ); antennomere 1 strongly darkened, 2-6 mostly yellowish, 7 partially obscured, 8-11 clearly blackened; length of each antennal segment proportional to numerical sequence 11:8:7:7:7:6:6:6:6:6:10.
Pronotum transverse, subtrapezoidal $(\mathrm{LP}=0.51 \mathrm{~mm}$; $\mathrm{WP} / \mathrm{LP}=1.92$ ), laterally almost straight; lateral and basal margin finely bordered; anterior angles not thickset, apparently without setigerous pore; punctation densely and strongly impressed on clearly microreticulate surface.

Elytra elongate $(\mathrm{LE}=1.47 \mathrm{~mm} ; \mathrm{LE} / \mathrm{LP}=2.89)$, entirely covering pygidium; laterally rounded; punctation arranged in 9 regular rows $(+2$ scutellar interrupted at basal fourth); large but moderately impressed punctulation on the whole surface; interstriae flat with finely shagreened surface; humeral callus present; macropterous. Scutellum subtriangular, with shagreened surface.

All femora distinctly blackened with evident metallic reflection; tibiae and tarsi partially but clearly darkened; hind tibiae with obtuse lateral dilation, and reddish and very short apical spur; 1 st anterior and middle tarsomere clearly dilated, subtriangular.

Ventral part black with weak metallic reflection. Last sternite with sparse but well impressed punctation; surface almost smooth; special preapical impressions absent.

Median lobe of aedeagus (Fig. 20) moderately slender $(\mathrm{LAED}=0.83 \mathrm{~mm}$; LE/LAED $=1.77)$; in ventral view apically rounded with and evident median truncate small tooth; ventral sulcus narrow but clearly impressed; median lobe in lateral view moderately and regularly curved.

PARATYPES: $\delta^{\top}: \mathrm{LB}=1.89 \mathrm{~mm} ; \mathrm{LAN}=1.01 \mathrm{~mm} ; \mathrm{LP}=$ $0.52 \mathrm{~mm} ; \mathrm{WP}=0.81 \mathrm{~mm} ; \mathrm{LE}=1.36 \mathrm{~mm} ; \mathrm{WE}=0.99$ $\mathrm{mm} ; \mathrm{LAED}=0.77 \mathrm{~mm} ; \mathrm{LAN} / \mathrm{LB}=0.53 ; \mathrm{WP} / \mathrm{LP}=1.56$; 


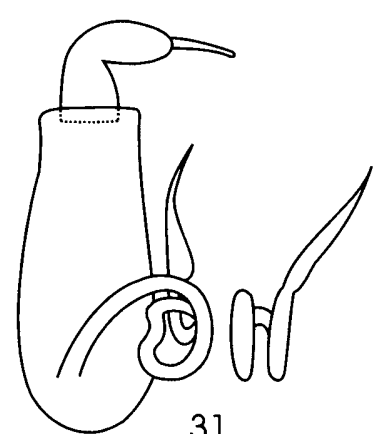

31
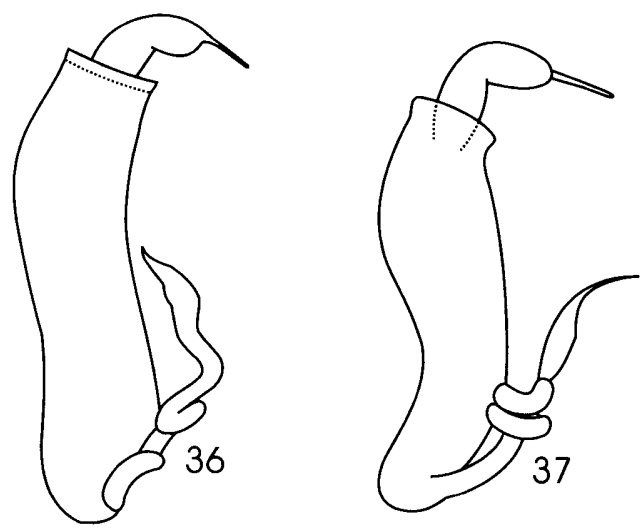

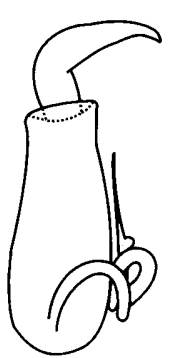

32
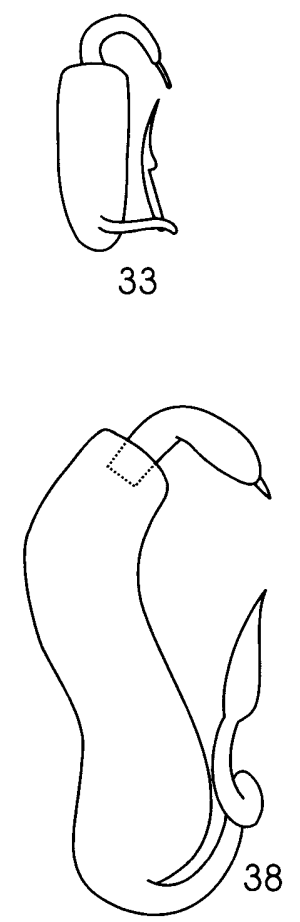

33
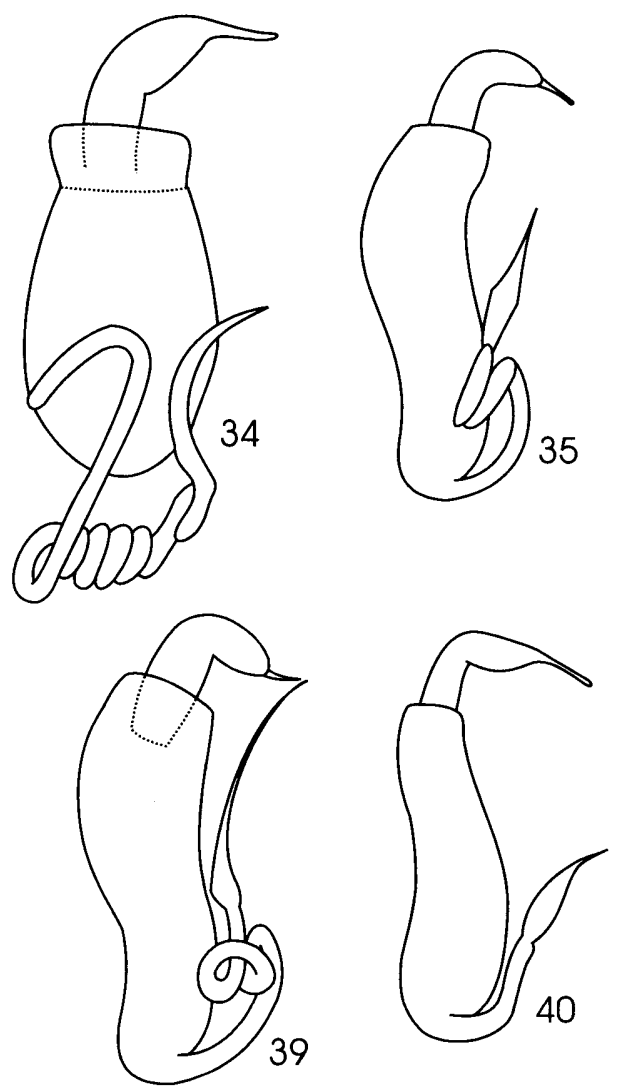

Figs 31-40. Spermatheca in Chaetocnema species: C. gregaria Weise, Madagascar, Maromandia (31); C. vadoni Bechyné, Madagascar, Pays Androy (32); C. orophila n. sp., Madagascar, Amparafara, paratype (33); C. similis Weise, Madagascar, Toamasina (34); C. bamakoensis Bechyné, Central-Southern Madagascar (35); C. consobrina Weise, type (36); C. basipunctata Bechyné, Madagascar, Tananarive (37); C. wollastoni Baly, Madagascar, Tananarive (38); C. ganganensis Bechyné, Madagascar, Analamerana (39); C. pauliani Bechyné, Madagascar, Anjanaharibe (40).

$\mathrm{LE} / \mathrm{LP}=2.61 ; \mathrm{LE} / \mathrm{LAED}=1.76$. Female of this new species is unknown. The paratype $\delta$ is very similar in colour and sculpturing to the holotype but slightly more immature.

Diagnosis. This new species is very closely related to C. pauliani from Madagascar and C. antennata Jacoby, 1897 from Southern Africa. The most important common characters are the similar body shape and the particular shape of the median lobe of the aedeagus. However, $C$. hygrophila is distinguishable from $C$. antennata by the coarse punctation on the head, the almost smooth surface of the pronotum (clearly shagreened in C. antennata) and the different shape of the apical part of the median lobe of the aedeagus, which is more elongate and with a more robust median small tooth in C. hygrophila n.sp. than in C. antennata. This new species can be distinguished from C. pauliani by the following characters: head and pronotum have a weakly microreticulate surface (clearly microreticulate in C. pauliani); antennal segments 1 and 8-11 strongly blackened (pale or slightly obscured in $C$. pauliani); antennomere 8 subglobose in male (subtriangular in C. pauliani); anterior and middle femora decisively darkened (pale in C. pauliani); dorsal integument with metallic cupreous reflection (bright green in $C$. pauliani); apical part of median lobe of aedeagus more lanceolate with median small tooth more robust, apically truncate (less lanceolate with median small tooth less robust apically acute in C. pauliani) (Figs 19-20).

Type material. Holotype $\delta:$ Madagascar: "Ambohitantely" [18.10S 47.17E], "dans depression humide, km 102 route Ankazobe, 6.ii.1948, leg. P. Cachan" (MNHN) [erroneously reported by Bechyné (1964) as $C$. fraterna Harold]. Paratype: Madagascar: "Madagascar Est, Chaînes anosyennes, Massif nord, 1900 m, haute Ranomandry" [24.15S 46.56E], "17/26.xi.1971, mission C.N.R.S.", 1 ô(MNHN).

Etymology. The name of this new species refers to the fact that it is found in moist environments.

Distribution. Madagascar.

Bionomics. Species found in moist environments ("dans depression humide") and probably associated with Oryza sp. (Gramineae) as is C. pauliani.

\section{Chaetocnema madagascariensis Baly}

Chaetocnema madagascariensis Baly, 1877: 309-310

Chaetocnema madagascariensis Baly: Weise, 1910: 435

Material examined. Madagascar: Antananarivo [18.54S 47.29E], leg. C. Lamberton, 2 exx. (MNHN).

Distribution. Central Madagascar.

Bionomics. No ecological information is available for this species.

Comments. The original description of C. madagascariensis was based on a single specimen labelled "Madag." and preserved in the BMNH (Baly, 1877). I 
examined this type specimen, which is unfortunately almost completely destroyed but for a little of the ventral parts and the legs, which are not useful for the identification of the species. In the entomological collections of the MNHN I found two specimens (male and female) that fit very well with the original description of C. madagascariensis. These specimens are briefly described. Dorsal integument blackish with an evident metallic bronze reflection, especially on pronotum. Body shape elongate, with pronotum and elytra laterally subparallel. Antennae basally pale; interantennal space wide and impunctate. Head and pronotum finely but densely punctate; surface clearly microreticulate. Pronotum with anterior angles distinctly raised, apically slanted; pronotal base deeply bordered with a line of well impressed punctules. Elytra entirely covering pygidium; interstriae with sparse fine punctules; humeral callus evident; macropterous. Tibiae and tarsi reddish; anterior and middle femora partially darkened; hind femora blackish.

§: $\mathrm{LB}=2.40 \mathrm{~mm} ; \mathrm{LAN}=1.63 \mathrm{~mm} ; \mathrm{LP}=0.59 \mathrm{~mm}$; $\mathrm{WP}=1.01 \mathrm{~mm} ; \mathrm{LE}=1.84 \mathrm{~mm} ; \mathrm{WE}=1.28 \mathrm{~mm} ; \mathrm{LAED}=$ $0.83 \mathrm{~mm} ; \mathrm{LAN} / \mathrm{LB}=0.68 ; \mathrm{WP} / \mathrm{LP}=1.73 ; \mathrm{LE} / \mathrm{LP}=3.14 ;$ $\mathrm{LE} / \mathrm{LAED}=2.23$. 1 st anterior and middle tarsomere very weakly dilated. Median lobe of aedeagus (Fig. 8) slender; in ventral view laterally subparallel and apically lanceolate; in lateral view weakly but regularly curved; ventral sulcus little visible; dorsal sulcus visible in apical third.

o: $\mathrm{LB}=2.51 \mathrm{~mm}$; LAN (antennae partially missing); $\mathrm{LP}=0.61 \mathrm{~mm} ; \mathrm{WP}=1.04 \mathrm{~mm} ; \mathrm{LE}=1.87 \mathrm{~mm} ; \mathrm{WE}=$ $1.33 \mathrm{~mm} ;$ LSP $=0.29 \mathrm{~mm}$; LAN/LB (not available); $\mathrm{WP} / \mathrm{LP}=1.70 ; \mathrm{LE} / \mathrm{LP}=3.04 ; \mathrm{LE} / \mathrm{LSP}=6.36$. Female very similar to male but with 1 st anterior and middle tarsomere slightly narrower. Spermatheca (Fig. 30) with basal part elongate, subcylindrical, and ductus elongate with two wide coils.

Of the Chaetocnema species occurring in Madagascar, C. madagascariensis is very close to $C$. cachani $\mathrm{n}$. $\mathrm{sp}$., but it is easily distinguished by the characters given in the key.

\section{Chaetocnema malgascia n. sp.}

Description. Holotype $(\delta)$ : dorsal integument black with clear metallic greenish reflection especially on head and pronotum. Body shape elongate-elliptical, little convex $(\mathrm{LB}=1.87 \mathrm{~mm})$. Maximum pronotal width at base: $0.72 \mathrm{~mm}$; maximum elytral width in basal fourth: $0.99 \mathrm{~mm}$.

Head clearly shagreened on vertex, interocular space with distinct punctulation; frontal grooves finely but clearly impressed; frontal tubercles absent; interantennal space very narrow; frontal carina narrow, moderately raised, laterally delimited by two fine grooves; labrum piceous, subrectangular, with six preapical setae; palpi piceous; antennae about half as long as body (LAN/LB = 0.63 ); antennomeres 1-3 yellowish, 4-5 partially darkened, 6-11 brown; length of each antennal segment proportional to numerical sequence $12: 8: 7: 7: 8: 7: 7: 8: 7: 7: 11$.

Pronotum weakly transverse $(\mathrm{LP}=0.44 \mathrm{~mm}$; WP $/ \mathrm{LP}=$ $1.63)$, wider at base, laterally moderately rounded; lateral margin clearly bordered; basal margin very finely bor- dered; anterior angles thickset, apically rounded, with a small setigerous pore; punctation densely impressed on clearly reticulate surface.

Elytra very elongate $(\mathrm{LE}=1.41 \mathrm{~mm} ; \mathrm{LE} / \mathrm{LP}=3.21)$, entirely covering pygidium; laterally moderately rounded; punctation arranged in 9 regular rows $(+1$ scutellar interrupted at basal fourth); punctules large and well impressed; interstriae subconvex, clearly and densely punctulate; humeral callus evident; macropterous. Scutellum very small, subtriangular, with shagreened surface.

Hind femora blackened with evident metallic reflection; anterior and middle femora darkened; tibiae and tarsi mostly pale; hind tibiae with lateral dilation very acute and very elongate reddish apical spur; 1st anterior and middle tarsomere elongate and moderately thickset.

Ventral part entirely piceous with weak metallic reflection. Last sternite distinctly punctulate with almost smooth surface; special preapical impressions absent.

Median lobe of aedeagus (Fig. 2) slender (LAED = $0.77 \mathrm{~mm}$; $\mathrm{LE} / \mathrm{LAED}=1.83$ ); in ventral view laterally subparallel, with lanceolate apical part; apex acute; ventral sulcus absent; dorsal sulcus visible only in apical fourth; dorsal ligula subtriangular, apically rounded; median lobe in lateral view distinctly curved and apically slightly sinuous.

Paratypes: $\delta:$ LB $=1.87 \pm 0.03 \mathrm{~mm} ; \mathrm{LAN}=1.17 \pm$ $0.03 \mathrm{~mm} ; \mathrm{LP}=0.47 \pm 0.02 \mathrm{~mm} ; \mathrm{WP}=0.73 \pm 0.01 \mathrm{~mm}$; $\mathrm{LE}=1.41 \pm 0.03 \mathrm{~mm} ; \mathrm{WE}=0.99 \pm 0.03 \mathrm{~mm} ; \mathrm{LAED}=$ $0.73 \pm 0.01 \mathrm{~mm} ; \mathrm{LAN} / \mathrm{LB}=0.63 \pm 0.01 ; \mathrm{WP} / \mathrm{LP}=1.57 \pm$ $0.07 ; \mathrm{LE} / \mathrm{LP}=3.03 \pm 0.16 ; \mathrm{LE} / \mathrm{LAED}=1.90 \pm 0.02$. $q$ : $\mathrm{LB}=2.09 \pm 0.11 \mathrm{~mm} ; \mathrm{LAN}=1.17 \pm 0.03 \mathrm{~mm} ; \mathrm{LP}=0.49$ $\pm 0.05 \mathrm{~mm} ; \mathrm{WP}=0.78 \pm 0.05 \mathrm{~mm} ; \mathrm{LE}=1.58 \pm 0.05 \mathrm{~mm}$; $\mathrm{WE}=1.12 \pm 0.05 \mathrm{~mm} ; \mathrm{LSP}=0.25 \pm 0.01 \mathrm{~mm} ; \mathrm{LAN} / \mathrm{LB}$ $=0.56 \pm 0.01 ; \mathrm{WP} / \mathrm{LP}=1.59 \pm 0.08 ; \mathrm{LE} / \mathrm{LP}=3.21 \pm$ $0.25 ; \mathrm{LE} / \mathrm{LSP}=6.34 \pm 0.31$. Female generally bigger, with 1 st tarsomere of anterior and middle legs clearly narrower. Spermatheca (Fig. 22) with basal part elongate, subcylindrical, and ductus with a coil. Paratypes similar in colour and sculpturing to the holotype.

Diagnosis. This species is attributed to the subgenus Tlanoma Motschulsky, 1845 and occurs in Madagascar along with the widespread species bilunulata, confinis, picipes and pulla. However, C. malgascia $\mathrm{n}$. sp. shows the closest affinities with Oriental species such as the Asiatic C. discreta (Baly, 1877), from which it is distinguishable mainly by the shape of the median lobe of the aedeagus and spermatheca.

Type material. Holotype $\delta$, Madagascar: "Region Mandritsara" [19.32S 47.03E], "leg. J. Vadon" (MNHN). Paratypes: Madagascar: same locality, date and collector of the holotype, 1 3 and 2 o (MNHN); "Ihosy" [18.33S 46.57E], 1901, "leg. C. Alluaud", 1 क (MNHN); "Tamatave" [= Toamasina: 18.08S 49.24E], 2 and 2 (NHMB: Coll. Frey); "Soavina" [20.23S 46.54E], "Nord-Ouest d'Ambositra, i.1951, leg. R. Paulian", 1 ๆ. (MNHN); "Ihosy" [24.09S 46.35E], "Region Sud de 1'ile, xi.1933, leg. A. Seyrig", 1 oै (NHMB: coll. Frey); "Madagascar Sud, pays Androy (Nord)" [24.20S 45.06E], "1900, leg. C. Alluaud", 1 and 2 (MNHN); "Madagascar Centre-Sud, 1901, leg. C. Alluaud", 2 (MNHN). 

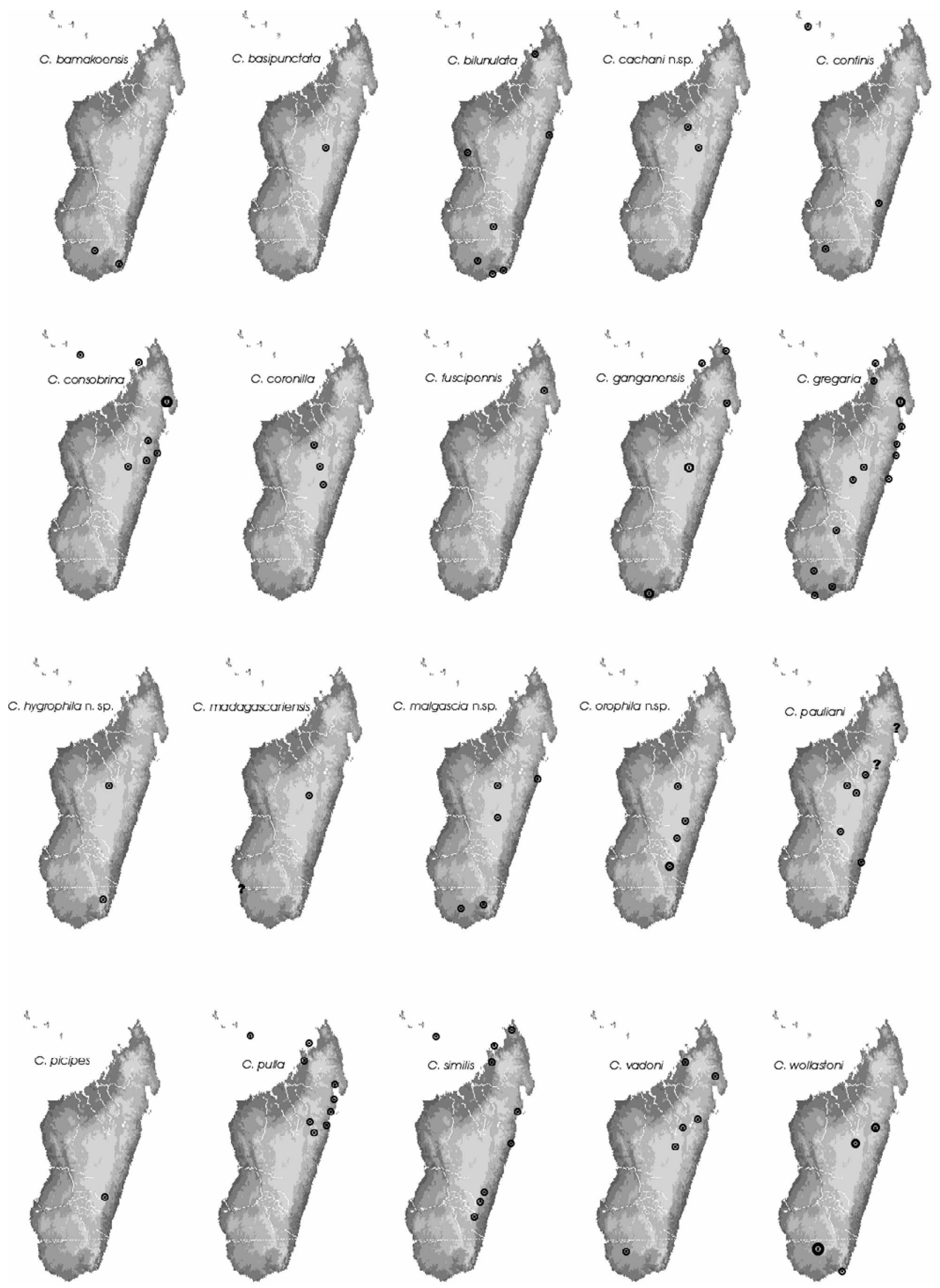

Fig. 41. Distribution maps of the Chaetocnema species in Madagascar and Comoro Islands. 


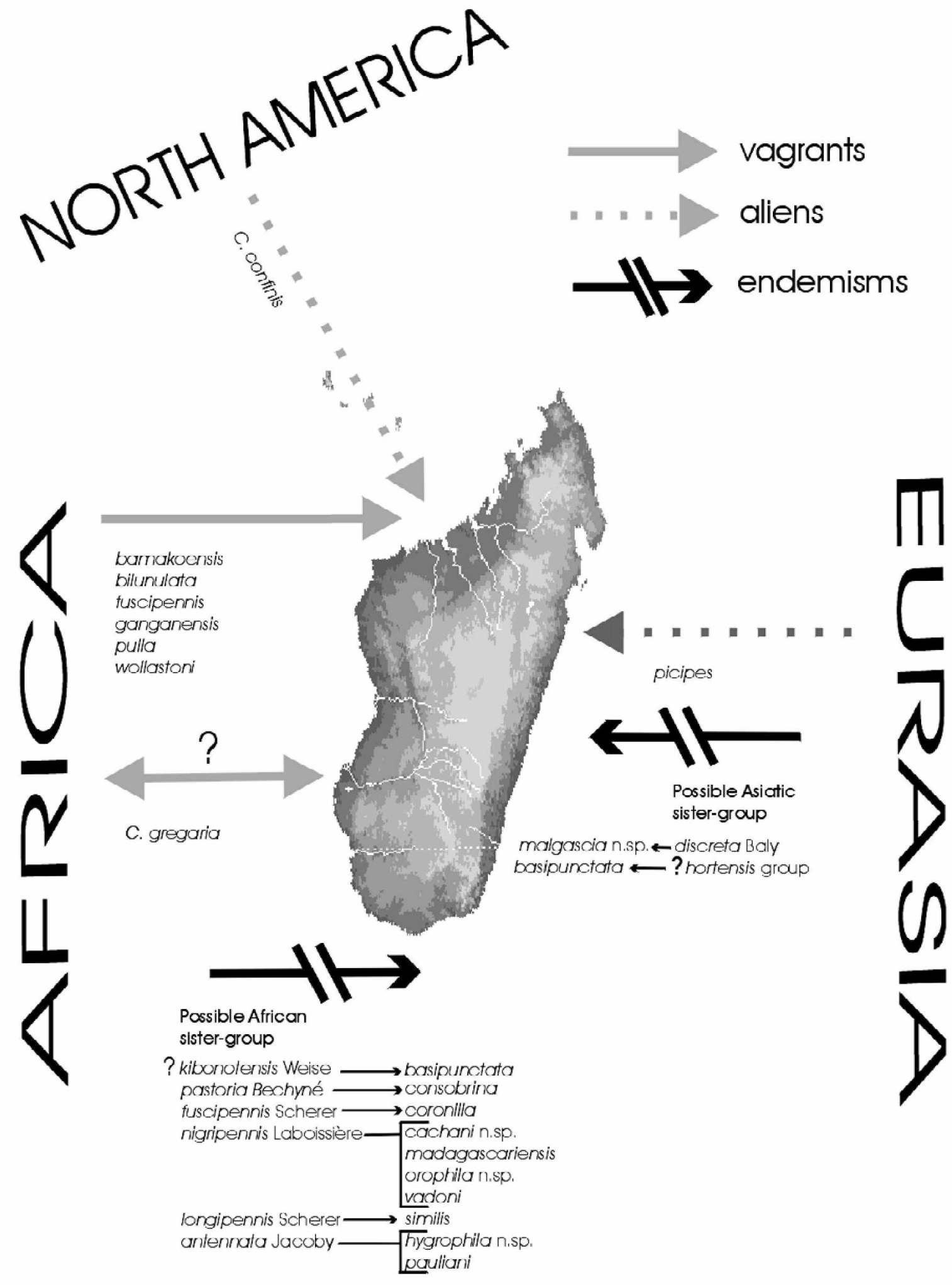

Fig. 42. Possible routes by which Chaetocnema species colonized Madagascar. 
Etymology. The name of this new species refers to where it was first found, Madagascar.

Distribution. Madagascar.

Bionomics. No ecological information is available for this species.

\section{Chaetocnema orophila $\mathbf{n}$. sp.}

Chaetocnema insularis Weise: sensu Scherer, 1962a: 65.

Description. Holotype ( $\delta$ ): dorsal integument black with weak metallic reflection. Body shape thicksetelliptical, convex $(\mathrm{LB}=1.41 \mathrm{~mm})$. Maximum pronotal width at middle: $0.67 \mathrm{~mm}$; maximum elytral width at basal third: $0.8 \mathrm{~mm}$.

Head sparsely and finely punctate with a finely shagreened surface; frontal grooves clearly impressed; frontal tubercles absent; interantennal space wide; frontal carina flat, laterally delimited by some coarse punctules; labrum reddish brown, short, subtrapezoidal, with six preapical setae; palpi reddish; antennae longer than half body length ( $\mathrm{LAN} / \mathrm{LB}=0.74$ ); antennomeres $1-5$ pale, 6-11 gradually darker; length of each antennal segment proportional to numerical sequence $9: 7: 6: 5: 7: 6: 8: 8: 8: 8: 12$

Pronotum clearly transverse $(\mathrm{LP}=0.39 \mathrm{~mm}$; WP $/ \mathrm{LP}=$ 1.72), subrectangular, laterally moderately rounded; lateral and basal margin clearly bordered; anterior angles moderately thickset, apically slanted, with a small setigerous pore; punctation very finely and sparsely impressed; surface clearly microreticulate; pronotal base with an evident line of punctules.

Elytra elongate $(\mathrm{LE}=1.07 \mathrm{~mm} ; \mathrm{LE} / \mathrm{LP}=1.63)$, entirely covering pygidium; laterally rounded; punctules arranged in 9 regular rows (+ 1 scutellar interrupted at middle); punctules large but moderately impressed; interstriae almost smooth, weakly convex; humeral callus present; macropterous. Scutellum subtriangular with shagreened surface.

All femora brownish, tibiae and tarsi mostly reddish; hind tibiae with obtuse lateral dilation and short reddish apical spur; 1st anterior and middle tarsomere moderately thickset, subtriangular.

Ventral part mostly piceous with very weak metallic reflection. Last sternite with subrugose surface; special preapical impressions absent.

Median lobe of aedeagus (Fig. 12) moderately slender $(\mathrm{LAED}=0.53 \mathrm{~mm}$; $\mathrm{LE} / \mathrm{LAED}=2.00)$; in ventral view laterally subparallel and apically lanceolate; ventral sulcus weakly impressed in distal half; median lobe in lateral view weakly but almost regularly curved.

Paratypes: $:$ LB $=1.54 \pm 0.26 \mathrm{~mm} ;$ LAN $=1.07 \pm$ $0.03 \mathrm{~mm} ; \mathrm{LP}=0.44 \pm 0.07 \mathrm{~mm} ; \mathrm{WP}=0.72 \pm 0.10 \mathrm{~mm}$; $\mathrm{LE}=1.19 \pm 0.17 \mathrm{~mm} ; \mathrm{WE}=0.72 \pm 0.10 \mathrm{~mm} ; \mathrm{LAED}=$ $0.57 \pm 0.06 \mathrm{~mm} ; \mathrm{LAN} / \mathrm{LB}=0.72 \pm 0.07 ; \mathrm{WP} / \mathrm{LP}=1.63 \pm$ $0.08 ; \mathrm{LE} / \mathrm{LP}=2.67 \pm 0.08 ; \mathrm{LE} / \mathrm{LAED}=2.06 \pm 0.09 .9$ : $\mathrm{LB}=1.68 \pm 0.11 \mathrm{~mm} ; \mathrm{LAN}=1.04 \pm 0.03 \mathrm{~mm} ; \mathrm{LP}=0.46$ $\pm 0.03 \mathrm{~mm} ; \mathrm{WP}=0.73 \pm 0.08 \mathrm{~mm} ; \mathrm{LE}=1.20 \pm 0.03 \mathrm{~mm}$; $\mathrm{WE}=0.93 \pm 0.03 \mathrm{~mm} ; \mathrm{LSP}=0.17 \pm 0.02 \mathrm{~mm} ; \mathrm{LAN} / \mathrm{LB}$ $=0.62 \pm 0.03 ; \mathrm{WP} / \mathrm{LP}=1.60 \pm 0.03 ; \mathrm{LE} / \mathrm{LP}=2.63 \pm$ $0.11 ; \mathrm{LE} / \mathrm{LSP}=7.11 \pm 0.21$. Female generally bigger, with 1st tarsomere of anterior and middle legs slightly narrower. Spermatheca (Fig. 33) with basal part elongate, subcylindrical and ductus with a wide coil. Paratypes in color and sculpturing similar to the holotype, but sometimes with elytral interstriae more or less convex.

Diagnosis. This new species is close to other Madagascar species such as C. vadoni, C. cachani, and $C$. madagascariensis, but it is easily distinguishable by the smaller size, the pronotum comparatively more transverse and the different shape of median lobe of aedeagus and spermatheca.

Type material. Holotype ठ, Madagascar: "Amparafara" [20.00S 47.56E], "iv/v.1937, leg. J. Vadon" (MRAC) (cf. Scherer, 1962a; reported as C. insularis Weise). Paratypes: same locality, date and collector of the holotype, $2 \delta$ and 1 \& (MRAC), 1 o (NHMB: coll. Frey); "Ambohitantely" [18.10S 47.17E], "dans depression humide, $\mathrm{km} 102$ route Ankazobe, 6.ii.1948, leg. P. Cachan", 1 (MNHN); "Madagascar Centre, Ambatofitorahana" [20.48S 47.10E], "1800 m, 31.xii.1972, leg. A. Peyrieras", 1 (MNHN); "Andrigitra Est, Anjavidilava" [22.19S 46.57E], “1850-1950 m, 18.xii.1970/15.i.1971”, 1 क (MNHN); "Madagascar Centre, Adringitra Sud" [22.25S 46.54E], "Andrianony cirque, Manjarivolo, $1650 \mathrm{~m}$, 26.x/3.xi.1970, mission C.N.R.S.", 2 (MNHN); "Madagascar, lot. 1 A-B-C- (155), leg. P. Cachan", 1 i (NHMB: Coll. Frey).

Etymology. Named for its affinity for montane environments.

Distribution. Eastern Madagascar.

Bionomics. Species found at middle to high altitudes, probably in moist environments ("dans depression humide" in Ambohitantely).

\section{Chaetocnema pauliani Bechyné}

Chaetocnema pauliani Bechyné, 1964: 156

Chaetocnema pauliani Bechyné: Scherer, 1962a: 65

Material examined. Madagascar: "Amparafaravola" [17.45S 48.12E], "Ouest du Lac Alaotra, 1921, leg. R. Decary", 1 paratype (MNHN); Ambohitantely [18.10S 47.17E], moist environment, km 192 road to Ankazobe, 26.ii.1948, leg. P. Cachan, 2 exx. (NHMB: Coll. Frey); Antananarivo [18.54S 47.29E], 1921, leg. R. Decary, 5 exx. (MNHN); "Tananarive" [= Antananarivo], "Tzimbazaza" [18.55S 47.31E], "ii.1949, sur riz", holotype \& (MNHN); ditto, 1 paratype (NHMB: coll. Frey); Central Madagascar, Itremo Massif [20.30S 46.32E], 1615 m, 4/6.i.1973, leg. A. Peyrieras, 1 ex. (MNHN); Manakara [22.08S 48.01E], 10.ii.1967, leg. Y. Gomy, 1 ex. (BAQ).

Distribution. Madagascar.

Bionomics. Species found in moist environments on Oryza sp. (Gramineae).

Comments. As reported above C. hygrophila n. sp. and this species are very similar to C. antennata Jacoby, 1897 from Southern Africa. C. pauliani is distinguishable from this species mainly by the following characters: body shape thickset with elytra comparatively shorter (body shape more elongate in C. antennata); dorsal integument with evident bright metallic green reflection (dark green in C. antennata); antennae and legs mostly pale (mostly blackened in $C$. antennata); punctulation on head and pronotum strongly impressed, subrugose (more weakly impressed in C. antennata); elytral interstriae usually distinctly carinate (generally flat in C. antennata). 


\section{Chaetocnema picipes Stephens}

Chaetocnema picipes Stephens, 1831: 327

Plectroscelis laevicollis Thomson, 1866: 229 (synonymized by Booth \& Ower, 1997: 85-89)

Chaetocnema heikertingeri Lubischev, 1963: 858-863

(synonymized by Döberl, 1994: 114-115)

Material examined. Madagascar: Fianarantsoa Province, Ranomafana env. [21.15 S 47.26E], 28.i.-6.ii.1995, leg. I. Jeniš, 1 ex. (BAQ).

Geographical distribution. This species is widespread throughout most of the Palaearctic Region [cfr. Gruev \& Döberl, 1997: sub C.laevicollis (Thomson)] and its presence in Madagascar is puzzling. Very probably it was accidentally introduced by man as it is a pest of soybean (Leguminosae) (cf. Puppin, 1974: sub C. heikertingeri Lubischev).

\section{Chaetocnema pulla Chapuis}

Chaetocnema pulla Chapuis, 1879: 14

Chaetocnema tantilla Weise, 1910: 437-438 syn. nov.

Chaetocnema tantilla Weise: Bechyné, 1964: 155

Chaetocnema vadoni Bechyné: sensu Scherer, 1962a: 65 (misidentification)

Lectotype designation. The designation of the lectotype of $C$. tantilla Weise is appropriate because the original description of this species was based on several syntypes also from different localities. C. tantilla: lectotype o "NW-Madagascar, J. Nossibé, 10.xi.1895, leg. S. Voeltzkow", M. Biondi des. (ZMHB).

Material examined. Comoro Islands: Mayotte [12.48S 45.09E], 22.x.1974, Coconi leg., 2 exx. (MNHN; det. by Bechyné as C. tantilla Weise,). Madagascar: "NW-Madagascar, J. Nossibé" [Nosy-be: 13.20S 48.16E], "10.xi.1895, leg. S Voeltzkow", lectotype $\delta$ of $C$. tantilla (ZMHB); ditto, 1.xi.1895, 2 exx. (paralectotypes of C. tantilla) (ZMHB); ditto, 5.xi.1895, 3 exx. (paralectotypes of $C$. tantilla) (ZMHB); ditto, 24.xi.1895, 1 ex. (paralectotype of $C$. tantilla) (ZMHB); Analalava Province, Maromandia [14.12S 48.05S], 1922, leg. R Decary, 17 exx. (MNHN); Maroantsetra [15.26S 49.44E], 4 exx. (NHMB: coll. Frey); Maroantsetra [15.26S 49.44E], at light, xii.1949, leg. J. Vadon, 1 ex. (erroneously reported by Scherer, 1962a as C. vadoni Bechyné) (MNHN); Eastern Madagascar, Maroantsetra District, Ivontaka [16.17S 49.49E], 8 m, iii.1958, leg. P. Soga - E. Raharizonina, 1 ex. (MNHN); SoanieranaIvongo [16.55S 49.34E], Fenoarivo-Atsinanana, viii.1904, leg. A. Mathiaux, 12 exx. (Bechyné, 1964: sub C. tantilla Weise) (MNHN; NHMB: Coll. Frey); "Oest Madagaskar, Fen,rive" [= Fenoarivo-Atsinanana: 17.22S 49.24], "vii.1904, streifsack, leg. S. Voeltzkow", 9 paralectotypes (ZMHB; NHMB: Coll. Frey); Lac Alaotra [17.29S 48.27E], 27.ii.1991, on rice, leg. P. Bousses, 4 exx. (CIRAD); ditto, 5.iii.1991, 6 exx. (CIRAD); Nosivola [17.43S 48.39E], 1 ex. (MNHN); Eastern Coast, forest, 1901, leg. C. Alluaud, 6 exx. (MNHN).

Distribution. Guinea, Sierra Leone, Ivory Coast, Nigeria, Sudan, Ethiopia, Kenya (Patte Island), Uganda, Rwanda, Burundi, Madagascar, Saudi Arabia, Yemen (Weise, 1910; Scherer, 1959, 1978; Doguet, 1984; Biondi, 1994); Republic of South Africa (personal data).

Bionomics. Species found in moist environments on Gramineae [Oryza sp. and Zea mays L. (cf. Bryant, 1928: sub C. zeae Bryant, 1926)].

\section{Chaetocnema similis Weise}

Chaetocnema similis Weise, 1910: 435-436

Chaetocnema similis Weise: Bechyné, 1964: 156

Lectotype designation. The designation of the lectotype of $C$. similis Weise is appropriate because the original description of this species was based on several syntypes also from different localities. C. similis: lectotype of "NW-Madagascar, J. Nossibé, 26.xi.1895, leg. S. Voeltzkow", M. Biondi des. (ZMHB).

Material examined. Comoro Islands: Mayotte, Chingoni [12.48S 45.08E], $70 \mathrm{~m}$, x.1958, leg. E. Raharizonina, 1 ex. (MNHN); Mayotte, Mamoudzou [12.47S 45.12E], ii.1956, leg. R. Andria, 1 ex. (MNHN). Madagascar: Ambohitra [12.31S 49.10E], 17.i.1968, leg. Y. Gomy, 2 exx. (ZMHB); "NWMadagascar, J. Nossibé" [Nosy-be: 13.20S 48.16E], "26.xi.1895, leg. S. Voeltzkow", lectotype of (ZMHB); ditto, 10.xi.1895, paralectotype (ZMHB); Analalava Province, Maromandia [14.12S 48.05S], 1922, leg. R. Decary, 2 exx. (MNHN); Soanierana-Ivongo $[16.55 \mathrm{~S} 49.34 \mathrm{E}]$, Fenoarivo-Atsinanana, viii.1904, leg. A. Mathiaux, 11 exx. (cf. Bechyné, 1964) (MNHN); Toamasina [18.08S 49.24E], 2 exx. (NHMB: Coll. Frey); Ranomafana, Ifanadiana [21.18S 47.38E], 1 ex. (MNHN); Tanala Forest [21.37S 47.30E], 1901, leg. C. Alluaud leg., (MNHN); "SO-Madagaskar, Ankarimbelo" [22.08S 47.19E], "16.v.1904, leg. S. Voeltzkow", paralectotype (ZMHB); Central-Southern Madagascar, 1901, leg. C. Alluaud, 1 ex. (MNHN).

Distribution. Madagascar and Comoro Islands.

Bionomics. No ecological information is available for this species.

Comments. Apparently this species belongs to the species-group that includes C. gregaria and related species, but its head is impunctate, pronotum clearly subtrapezoidal, and ductus spermathecae very elongate with many coils. For some of these characters this species seems more closely related to the African species C. longipennis Scherer, 1962.

\section{Chaetocnema vadoni Bechyné}

Chaetocnema vadoni Bechyné, 1948: 9-10.

Chaetocnema alaotrensis Bechyné, 1964: 158 syn. nov.

Material examined. Madagascar: "Prov. d'Analalava, Maromandia" [14.12S 48.05S], "1922, leg. R. Decary", 5 exx. (MNHN); "Andapa" [14.40S 49.39E], "xii.1937, leg. J. Vadon", holotype $\delta$ and 3 paratypes (MNHN); "Imerimandroso" [17.25S 48.35E], "rive $\mathrm{N}$ du Lac Alaotra, vi.1921, leg. R. Decary", holotype $\delta$ of $C$. alaotrensis, (MNHN); "Amparafaravola" [17.45S 48.12E], "Ouest du Lac Alaotra, 1921, leg. R. Decary", 4 paratypes of C. alaotrensis (MNHN; NHMB: Coll. Frey); Antananarivo [18.54S 47.29E], 1921, leg. R. Decary, 4 exx. (MNHN); Southern Madagascar, pays Androy (North) [24.20S 45.06E], 1900, leg. C. Alluaud, 1 ex. (MNHN).

Distribution. Madagascar.

Bionomics. No ecological information is available for this species but it is very probably restricted to moist environments. 


\section{Chaetocnema wollastoni Baly}

Chaetocnema wollastoni Baly, 1877: 167.

Chaetocnema dunbrodensis Jacoby, 1906: 17 (synonymized by Bryant, 1928: 395).

Chaetocnema fraterna Harold, 1879: 232 syn. nov.

Chaetocnema monomorpha Bechyné, 1964: 156-157 syn. nov.

Material examined. Madagascar: "Madagascar", type $q$ of C. fraterna (ZMHB); Lac Alaotra [17.36S 48.31E], 1 ex. (NHMB: Coll. Frey); "Sabotry" [18.49S 47.31E], "10 km N of Tananarive" [= Antananarivo], "8.i.1948, leg. R. Paulian", holotype $q$ of $C$. monomorpha (MNHN); Antananarivo [18.54S 47.29E], 1921, leg. R. Decary, 1 ex. (MNHN); ditto, leg. C. Lamberton, 2 exx. (MNHN); ditto, leg. J. Vadon, 4 exx. (MNHN); Antananarivo, Parc of Tsimbazaza [18.55S 47.31E], 26-31.x.1984, yellow pan traps, leg. R.W. Brooks, 1 ex. (KSBS); Tôlanäro [25.02S 46.59E], iii.1960, leg. J.E. Randriamasy, 1 ex. (MNHN); Tôlanäro [25.02S 46.59E], leg. R Paulian, 2 exx. (MNHN); Central-Southern Madagascar, 1901, Bechyné 1955, leg. C. Alluaud, 2 exx. (MNHN).

Distribution. Afrotropical Region, Yemen and Saudi Arabia (Scherer, 1978; Doguet, 1984; Furth, 1985; Tiberghien, 1976).

Bionomics. Species associated with Gramineae (cf. Tiberghien, 1976; Furth, 1985).

\section{CONCLUSIONS}

As reported above, at least 20 species of the genus Chaetocnema occur in Madagascar. The possible colonization routes of these species are given in Fig. 42. This scheme is based on preliminary results of a phylogenetic study on the groups of species of Chaetocnema now under preparation.

As expected, the endemism rate is rather high; that is notwithstanding that the species of this genus are generally macropterous and so potentially good dispersers, which generally limits local endemism. The endemic species of Chaetocnema in the Madagascar make up about $55 \%$ of the total.

The other Chaetocnema spp. in the Madagascar fauna can be subdivided into:

- vagrants: widespread species that very probably dispersed naturally from Continental Africa to Madagascar (C. bamakoensis, C. bilunulata, C. fuscipennis, C. ganganensis, C. pulla, C. wollastoni);

- aliens: species possibly introduced by man and mainly associated with the cultivation of exotic crop plants. This is surely the case for C. confinis Crotch associated with sweet potato and C. picipes Stephens associated with soybean.

At present little is known about the Madagascar flea beetle fauna. Future investigations will definitely add new taxa and a significant amount of new data about the local distribution of species. For example, looking at the distributional maps (Fig. 41), it is clear that most Chaetocnema species in Madagascar are from the eastern part of the island. This partly due to the richness of the moist environments in this area (very important for almost all species of this flea beetle genus) and partly due to being the most investigated. In contrast little data exist for the western part of Madagascar, which is more xeric with extensive deciduous forests and shrubbery (cf. Du Puy \& Moat, 1996).

ACKNOWLEDGEMENTS. I am very grateful to colleagues who enabled me to study the valuable material preserved in their respective institutions: S. L. Shute (BMNH), M. De Meyer (MRAC), M. Uhlig and H. Wendt (ZMHB), H. P. Aberlenc (CIRAD); N. Berti (MNHN); L. Bartolozzi (MZUF); E. Sprecher (ZMHB). I wish to thank also my friends S. Doguet and M. Bergeal (Paris) for having provided me with material from their collections, and D. G. Furth (Washington) for his linguistic improvements to my manuscript.

\section{REFERENCES}

BALY J.S. 1877: Descriptions of new genera of uncharacterized species of Halticinae. Trans. Entomol. Soc. Lond. 1877: 157-184; 283-323.

BeCHYNÉ J. 1948: De novis speciebus Halticidarum Madagascariensis (Col. Phytophaga). Čas. Čsl. Spol. Entomol. 45: 3-11.

BeCHYNÉ J. 1955: Über die westafrikanischen Alticiden (Col. Phyt.). Entomol. Arb., Mus. Frey 6: 486-568

BeCHYNÉ J. 1960: Notes sur les Alticides africains des collections de l'Institut royal des Sciences naturelles de Belgique (Coleoptera, Phytophaga). Bull. Inst. R. Sci. Nat. Belgique 36: $1-32$.

BECHYNÉ J. 1964: Notizen zu den madagassischen Chrysomeloidea (Col.Phytophaga). Mitt. Münch. Entomol. Ges. 54: 68-161.

Biondr M. 1994: Contributo alla conoscenza dei Chrysomelidae Alticinae (Coleoptera) della Sierra Leone. 1a. Nota. Quaderni Accad. Nazionale Lincei 267: 423-438.

Booth R.G. \& OWER J.A. 1997: Chaetocnema picipes Stephens (Chrysomelidae: Alticinae) in Britain. Coleopterist 6(3): 85-89.

Bryant G.E. 1928: Revision of the African Species of Chaetocnema (Col., Halticidae). Ann. Mag. Nat. History 10: 393-407.

Chapurs F. 1879: Phytophages Abyssiniens du Musée civique d'Histoire naturelle de Génes. Ann. Mus. Civ. Storia Nat. Genova 15: 5-31.

Crotch G.R. 1873: Materials for the study of the Phytophaga of the United States. Proc. acad. Nat. Sci. Phil. 25: 19-83

Demaison C. 1902: Description de trois Coléoptères phytophages nouveaux d'Europe et d'Égypte. Bull. Soc. Entomol. Fr. 1902: 24-25.

DöBERL M. 1994: Nachtrag zu Bd.9 "die Käfer Milteleuropas", Chrysomelidae, Alticinae. m: Lohse G.A. \& Lucht W. "Die Käfer Milteleuropas”, Bd.14. Goecke \& Evers, Krefeld, pp. 92-141.

Doguet S. 1984: Insects of Saudi Arabia. Coleoptera: Fam. Chrysomelidae, Subfam. Alticinae (Part 2). Fauna Saudi Arabia 6: 361-366.

Du PuY D.J. \& Mонт J. 1996: A refined classification of the primary vegetation of Madagascar based on the underlying geology: using GIS to map its distribution and to assess its conservation status. Actes Colloque Internat. "Biogéographie de Madagascar", Paris, Sept.1995. Orstom, Paris, pp. 205-218.

FurTh D.G. 1985: Some flea beetles and their foodplants from Kenya (Chrysomelidae: Alticinae). Coleopterists Bull. 39(3): 259-263.

GRUev B. \& Döberl M. 1997: General distribution of the Flea Beetles in the Palaearctic subregion (Coleoptera, Chrysomelidae: Alticinae). Scopolia 37: 1-496.

Harold E. 1879: Diagnosen neuer Arten. Coleopterologische Hefte 16: 225-232. 
JACOBY M. 1906: Descriptions of new genera and species of African Halticinae and Galerucinae. Trans. Entomol. Soc. Lond. 1906: 11-52.

Jolvet P. 1979: Réflexions sur l'écologie, l'origine et la distribution des Chrysomélides (Col.) des fles Mascareignes, avec la description de deux espèces nouvelles. Bull. Mensuel Soc. Linn. Lyon 48: 524-649.

Jolnvet P. 1998: Les nouveaux envahisseurs ou les Chrysomélides voyageurs (Col.). L'Entomologiste 54(1): 33-44.

Laborssière V. 1942: Halticinae (Coleoptera Phytophaga). Fam Chrysomelidae. Exploration du Parc National Albert. Mission G.F. de Witte (1933-1935). Institut Parcs Nationaux Congo Belge (Bruxelles) 39: 1-131.

LuBISCHEV A.A. 1963: Two new palearctic species of the genus Chaetocnema of the group Ch. concinna Marsh. (Coleoptera, Chrysomelidae, Halticinae). Rev. Entomol. Urss 42: 858-863.

MaUuIK S. 1931: Coleoptera Chrysomelidae, Eumolpinae, Galerucinae and Halticinae. Percy Sladen Trust Expedition to the Indian Ocean in 1905. Trans. Linn. Soc. Lond. (Zoology) 19 241-260.

PIC M. 1909: Descriptions ou diagnoses et notes diverses. $L ' E$ change. Rev. Linn. 25: 137-139.

PIC M. 1911: Sur divers Altisides du Nord de l'Afrique avec description de plusieurs formes nouvelles (Col. Chrysomelidae). Bull. Soc. Entomol. Fr. 1911: 9-11.

PUPPIN O. 1974: Rinvenimento in Italia di Chaetocnema heikertingeri Ljub. (Coleoptera Chrysomelidae) nuovo potenziale nemico della soia. Boll. Zool. Agr. Bachicoltura (Serie II) 12: 201-204.

Reitter E. 1906: Neue Coleopteren aus der palaearktischen Fauna. Wiener Entomol. Ztg. 25: 31-37.

Scherer G. 1959: Die Alticiden-Ausbeute der Expedition des Museums G. Frey nach Nigeria-Kamerun 1955/56 (Col. Phytoph.). Entomol. Arb. Mus. Frey 10: 177-265.
Scherer G. 1962a: Beitrag zur kenntnis der Alticiden-fauna Zentral-Afrikas (Coleoptera Chrysomelidae Alticinae). Annls. Mus. R. Congo Belge (Sci. Zool.) 113: 1-82.

Scherer G. 1962b: Alticinae (Coleoptera Phytophaga). Fam. Chrysomelidae. Parc National de la Garamba. Mission H. De Saeger (1949-1952). Institut Parcs Nationaux Congo Rwanda (Bruxelles) 31(1): 3-86.

SCHERER G. 1969: Contributions à la connaissance de la faune entomologique de la Côte-d'Ivoire (J. Decelle, 1961-1964). XLIII. Coleoptera Chrysomelidae Alticinae. Annls. Mus. R. Congo Belge 175: 365-371.

SCHERER G. 1972: Coleoptera aus Nordostafrika. Chrysomelidae: Alticinae. Notulae Entomologicae 52: 1-17.

Scherer G. 1978: Missione 1965 del professor Giuseppe Scortecci nello Yemen (Arabia Meridionale). Coleoptera Chrysomelidae: Alticinae. Atti Soc. It. Sci. Nat. (Milano) 119 (3-4): 264-266.

StePHENS J. 1831: Illustrations of British Entomology. IV. Mandibulata. Baldwin \& Cradok, London, $408 \mathrm{pp}$.

Thomson C.G. 1866: Scandinaviens Coleoptera. tom. VIII. Lundbergska Boktryckeriet, Lund, pp. 105-279.

Trberghien G. 1976: Coléoptères Chrysomeloidea de la République du Tchad. 1re note: Cryptocephalinae, Alticinae, Cassidinae, Hispinae. Bull. Mensuel Soc. Linn. Lyon 45(5): 176-181.

VIETte P. 1991: Principales localités où des Insectes ont été recueillis à Madagascar. Faune de Madagascar 2: $88 \mathrm{pp}$.

WeISE J. 1910: Chrysomelidae von Madagascar, den Comoren, und den Inseln (östafrikas). In S. Voeltzkow: Reise in (östafrika) in den Jahren 1903-1905, Band II, Heft 5. E. Schweizerbartsche Verlagsbuchhandlung, Nägele \& Dr. Sproesser, Stuttgart, pp. 419-506.

Received February 22, 2000; accepted June 9, 2000 